\title{
JOONAS PENNANEN
}

\section{TULKINTOJA OLENNAISESTI \\ KIISTELLYISTÄ KÄSITTEISTÄ ${ }^{1}$}

JOHDANTO

Vuonna 2016 tulee kuluneeksi 60 vuotta Walter Bryce Gallien (1912-98) suurta huomiota osakseen saaneen artikkelin "Essentially Contested Concepts" (Gallie 1956a) julkaisusta. Kyseisessä artikkelissa Gallie esittää taajaan kommentoidun teesinsä "olennaisesti kiistellyistä käsitteistä" (essentially contested concept ${ }^{2}$ ). Gallien mukaan voidaan tunnistaa joukko käsitteitä, jotka tuovat väistämättä mukanaan päättymättömiä mutta kuitenkin täysin aitoja kiistoja varsinaisista käyttötavoistaan. Näissä kiistoissa osapuolet puolustavat parhaana pitämäänsä käyttötapaa vakuuttaviksi katsomiensa perustelujen nojalla. Osapuolet eivät "puhu toistensa ohi"- he kiistävät tällöin yhden ja vain yhden käsitteen käyttötavan - eikä heidän järkeviksi katsomiaan perusteluita tarvitse pitää tiedostamattomina rationalisointeina eikä pelkkinä erityisten intressien osoituksina. Asiaa ei myöskään tarvitse nähdä"metafyysisen"tason älyllisenä tai filosofisena erimielisyytenä, vaan kiistojen uppiniskaisuus ja läpitunkevuus on selitettävissä muulla tavoin. Sikäli kuin yleinen käyttötapa on mielekkäästi hahmotettavissa, sen on nähtävä koostuvan toisensa kiistävistä erityisemmistä käytöistä. Reaalimaailman esimerkkeinä tällaisista käsitteistä Gallie mainitsee taiteen, demokratian, sosiaalisen oikeudenmukaisuuden ja kristillisyyden ${ }^{3}$.

Lähtökohtana on hyvin arkipäiväinen huomio: tietyt yleisesti käyttämämme käsit- teet, kuten sosiaalinen oikeudenmukaisuus ja demokratia, näyttävät olevan äärimmäisen kiisteltyjä. Erimielisillä osapuolilla on omat perusteensa mielipiteelleen, jota he pitävät toisten näkemyksiä parempana, ja usein kyseiset perusteet vaikuttavat sinänsä täysin järkeviltä ja asiaankuuluvilta. Se, ovatko kiistelijät "maallikkoja" vai jonkin yhteiskunnallisen alan erityisasiantuntijoita, ei tunnu helpottavan yhteisymmärrykseen pääsyä. Pitkä historia enemmän tai vähemmän epäonnistuneita ja vuorollaan kiistettyjä yrityksiä määrittää käyttämiemme keskeisten käsitteiden sisältö ei ole myöskään omiaan herättämään luottamusta siihen, että lopulliseen ratkaisuun voitaisiin ylipäätään edes päästä. Väite käsitteiden olennaisesta kiistanalaisuudesta alkaa tällöin helposti viehättää luvatessaan teoreettisen esityksen asiantilasta, joka arkijärjellä ajateltuna vaikuttaa itsestään selvältä tai vähintäänkin luultavalta.

Teoria olennaisesti kiistellyistä käsitteistä nähdään usein osana myöhäiswittgensteinilaisen kielifilosofian jatkumoa ${ }^{4}$. Gallien kattavana metateoreettisena tavoitteena on osoittaa "analyyttisen metodin", jonka hän tuntui samaistavan pyrkimykseen kohti universalismia ja essentialismia kaikilla tieteen aloilla, rajoittuneisuus tiettyjen tapauksien ja ilmiöiden analysoimisessa. Kyseinen lähestymistapa ei ansioistaan huolimatta auta selventämään nii- 
tä järjenkäytön piirteitä, jotka mahdollistavat uskonnollisia, poliittisia ja esteettisiä ongelmia koskevat keskustelut. Monen olennaisesti kiistanalaisista käsitteistä kiinnostuneen teoreetikon pyrkimyksenä onkin ollut selittää, miksi ihmistieteiden ja yhteiskuntatieteiden piirissä käytettävät käsitteet vaikuttavat huomattavasti luonnontieteellisiä käsitteitä kiistanalaisemmilta. Gallien kokonaisvaltainen ratkaisu on täydentää käsitteellistä analyysia historiallisella ymmärryksellä tutkimuksen kohteena olevien käsitteiden kehityksestä, minkä on tarkoitus selventää nykyisten käyttöjen erityispiirteiden lisäksi kyseisten käyttöjen kiisteltyä/kiistanalaista luonnetta. Toisaalta hänen teoriansa on tulkittavissa - erityisesti ECC-artikkelin pohjalta - esitykseksi käsitteen ja käsityksen (concept/conception) välisestä erosta (vrt. Besson 2005, 72). Gallien teoria onkin vaikuttanut myöhempiin näkemyksiin käsitteen ja käsityksen välisestä suhteesta ${ }^{5}$. Olennaisesta kiistanalaisuudesta on keskusteltu paljon esimerkiksi estetiikan tutkimuksen ja lakitieteiden piirissä, mutta ongelmakenttä on relevantti käytännössä kaikille yhteiskuntatieteilijöille ja humanisteille. Voidaan myös perustellusti väittää, että nykypäivän poliittisliberalistisessa ajattelussa olennaisen kiistanalaisuuden perusajatus on laajalti omaksuttu - olkoonkin, että päättymättömästä konfliktitilanteesta vedetyt (preskriptiiviset) johtopäätökset vaihtelevat huomattavasti6.

Käyn ensin lyhyesti läpi Gallien esittämät seitsemän ehtoa olennaisesti kiistellyille käsitteille. Valtaosa artikkelista käsittelee kuitenkin olennaisesta kiistanalaisuudesta - joksi kutsun analysoinnin kohteena olevaa ilmiötä - esitettyjä tulkintoja. Tarkoituksenani on vetää yleisiä suuntaviivoja klassisen kysymyksenasettelun "mistä olennainen kiistanalaisuus on seurausta?" puitteissa ${ }^{7}$. Näkemykseni mukaan kysymykseen voidaan vastata neljässä pääasiallisessa tulkintakehyksessä, joissa käsitteiden kiisteltävyys tai kiistanalaisuus näyttäytyy olennaisesti eri tavoin. Kyseiset neljä tulkintakehystä ovat: 1) käsitekeskeinen, jossa keskitytään käsittei- den sisäsyntyisiin ominaisuuksiin tai piirteisiin; 2) sosiaalinen, jossa tarkastellaan yhteiskunnallisia prosesseja ja vuorovaikutusmekanismeja; 3) historiallinen, jonka fokus on käsitteiden ajallisten muutosten jäljittämisessä ja/tai historiallisessa ymmärryksessä; ja 4) poliittinen, joka näkee olennaisen kiistanalaisuuden poliittisen ulottuvuuden jäsentämisenä tai artikulaationa. Kriittistä keskustelua olennaisesta kiistanalaisuudesta on vuosien kuluessa käyty lähinnä käsitekeskeisestä näkökulmasta, mitä pidän valitettavana. Jotta olennaista kiistanalaisuutta kyetään ymmärtämään ja analysoimaan, tulee Gallien kuvaama ilmiö ymmärtää aiempaa kokonaisvaltaisemmin. Näkemykseni mukaan Gallien teoria tavoittaa ajatuksia herättävällä tavalla sosiaalista elämäämme koskevan olennaisen asiantilan, mikä vielä tänäkin päivänä kiehtoo ihmisiä ympäri maailman. Väitän, että Gallien perimmäinen oivallus liittyy kuitenkin kiistelyn tapaan, ei niinkään kiistoissa usein käytettyjen käsitteiden erikoislaatuisuuteen muihin käsitteisiin nähden.

\section{GALLIEN SEITSEMÄN EHTOA}

Teoria olennaisesti kiistellyistä käsitteistä on varsin abstrakti. Gallie selventää näkemystään käyttäen apunaan keinotekoista esimerkkiä "mestaruuskilpailusta" (championship) ja päätyy esittämään seitsemän "puoli-formaalia" (ECC, 170) ehtoa, joita olennaisesti kiisteltyjen käsitteiden tulee noudattaa. Gallien esimerkkitapauksessa mestaruutta ei ratkaista tavanomaiseen (vuosittaiseen) tapaan voittoja, tappioita tai muita pistesuorituksia laskemalla. Kyse on pikemminkin "faniudesta", toisin sanoen jokaisella joukkueella on omat kannattajansa ja tukijansa, jotka arvostavat mieltymystensä mukaan erilaisia tapoja ja tyylejä pelata kyseistä peliä - Gallie itse käyttää esimerkkinä keilausta. Esimerkiksi jotkut arvostavat joukkueen kykyä toteuttaa erilaisia kierteitä toisten pitäessä nopeuteen perustuvaa pelaamista parempana. Eri 
joukkueiden ja pelitapojen kannattajat kiistelevät jatkuvasti siitä, mikä joukkue ansaitsee "todellisen mestarin" arvonimen, eli mikä joukkue pelaa peliä parhaiten. Kannattajien välinen kamppailu käy kuumana osapuolten pyrkiessä vakuuttamaan toisensa oman kantansa oikeellisuudesta. (ECC, 170-1; PHU, 160.) On vaikea välttyä mielikuvalta, että Gallie puhuu itse asiassa poliittisesta prosessista. "Todellinen mestari” ei tällöin ole esimerkiksi eniten ääniä saanut puolue, vaan erimielisillä osapuolilla on omat, mahdollisesti täysin kelvolliset syynsä jatkaa kiistelyä ilman mahdollisuutta julistaa yhtä tahoa yksiselitteisesti oikeassa olevaksi. Gallie ei kuitenkaan muodosta tätä yhteyttä eksplisiittisesti.

Esitän seuraavassa lyhyesti Gallien muotoilemat ehdot (E) ja nostan samalla esiin muutamia Gallien tekemiä huomioita, jotka koskevat yhtä "elävää esimerkkiä" (ECC, 180), demokratian käsitettä (D).

$\mathbf{E}_{\mathbf{1}}$ : Arvottavuus: Käsitteen tulee olla "arvottava siinä mielessä, että se merkitsee tai lukee ansioksi jonkinlaisen arvostetun saavutuksen" (ECC, 171; PHU, 161). Esimerkiksi sosiaalisen oikeudenmukaisuuden toteutuminen on epäilemättä arvostettu saavutus huolimatta näkemyseroista sen sisältöä koskien.

$\mathbf{D}_{1}$ : Gallien mukaan demokratia on "viimeisen sadanviidenkymmenen vuoden aikana $[. .$.$] ta-$ saisesti vakiinnuttanut paikkansa arvioivana poliittisena käsitteenä par excellence. Lukuun ottamatta tehokkuuden ja turvallisuuden kysymyksiä pääasiallinen kysymys, joka on koskenut mitä tahansa suurta politiikka-päätöstä, on tänä aikana ollut: onko se demokraattinen?" (ECC, 184; PHU, 179).

$\mathrm{E}_{2}$ : Monimutkaisuus: Käsitteen ansioksi lukeman "saavutuksen tulee olla luonteeltaan sisäisesti monimutkainen huolimatta siitä, että sen arvo liitetään siihen kokonaisuudessaan" (ECC, 171-2; PHU 161).

$\mathbf{D}_{2}$ : Gallie antaa kolme esimerkkiä demokratiakäsitteen eri piirteistä. Demokratia merkitsee pääasiallisesti "kansalaisten enemmistön valtaa valita (ja vaihtaa) hallintoja [...] kaikkien kansalaisten tasa-arvoa saavuttaa poliittisen johtajuuden ja vastuun asemia [...] kansalaisten jatkuvaa aktiivista osallistumista poliittiseen elämään sen kaikilla tasoilla" (ECC, 184-5; PHU, 179).

$\mathrm{E}_{3}$ : Moninainen kuvailtavuus: Selitettäessä saavutuksen arvoa tulee viitata sen moninaisten piirteiden ja osien osuuteen kokonaisarvon määräytymisessä. Eri piirteet voidaan asettaa erilaisiin tärkeysjärjestyksiin. Niinpä "ansioksi luettu saavutus on läbtökohtaisesti [initially] eri tavoin kuvailtavissa" (ECC, 172; PHU 161). Joka tapauksessa osapuolten tulee edes minimaalisesti arvostaa ja olla tietoisia myös muista (arvostettavista) piirteistä, joita keskustelu- tai kiistakumppanit saavutukseen liittävät (vrt. PHU 162).

$\mathbf{D}_{3}$ : Demokratian käsite on "sisäisesti monimutkainen siten, että mikä tahansa demokraattinen saavutus (tai ohjelma) sallii kuvauksien moninaisuuden, jossa sen eri aspektit luokitellaan osana erilaisia tärkeysjärjestyksiä” (ECC, 184; PHU, 179). Käsitellessään "demokratian" olennaisesti kiisteltyä luonnetta Gallie ei erotta toista ja kolmatta ehtoa vaan käsittelee niitä yhdessä.

$\mathbf{E}_{4}$ : Avoimuus: "Ansioksi luetun saavutuksen tulee olla sellainen, että se sallii huomattavia muunnelmia olosuhteiden muuttuessa. Tällaisia muunnelmia ei voi määrätä eikä ennustaa ennakkoon. Kätevyyden vuoksi kutsun jokaisen tällaisen saavutuksen käsitettä luonteeltaan 'avoimeksi'." (ECC 172; PHU 161.)

$\mathrm{D}_{4}$ :"Politiikan ollessa mahdollisen taidetta demokraattisia tavoitteita tullaan nostamaan ja laskemaan olosuhteiden muuttuessa ja demokraattisia saavutuksia arvioidaan aina tällaisten muutosten valossa" (ECC, 186; PHU, 180).

$\mathbf{E}_{5}$ : Vaihtoehtojen tunnustaminen: "[O]lennaisesti kiistellyn käsitteen käyttäminen merkitsee sen käyttöä toisia käyttötapoja vastaan ja 
samalla sen tiedostamista, että omasta käyttötavasta täytyy pitää kiinni näitä toisia käyttötapoja vastaan [...] olennaisesti kiistellyn käsitteen käyttäminen tarkoittaa käyttöä sekä hyökkäävästi että puolustavasti” (ECC, 172; PHU 161). Gallien mukaan neljä ensimmäistä ehtoa ovat tärkeimmät ja minkä tahansa olennaisesti kiistellyn käsitteen tulee noudattaa niitä; ne ovat välttämättömiä ehtoja. Ne eivät kuitenkaan "määritä, mitä on olla tämänkaltainen käsite" (mt.), ja tästä syystä tarvitaan myös viides ehto.

$\mathbf{D}_{5}$ : Gallie toteaa yksikantaan, että demokratian käsitettä käytetään hyökkäävästi ja puolustavasti, eikä asia tässä suhteessa vaadi enempää käsittelyä (ECC, 186; PHU, 180).

Eriteltyään edelliset viisi ehtoa, Gallie katsoo määritelleensä, mitä olennaisesti kiistellyt käsitteet ovat. Kyseisten viiden ehdon puitteissa on kuitenkin täysin mahdollista, että kiistelevät osapuolet eivät tosiasiallisesti puhu samasta asiasta eli käytä yhtä käsitettä asian identifioimiseen. Tällöin kyseessä olisi pikemminkin sekaannus käsitteen käyttöä koskien (confused use of a concept) kuin "aito" esimerkki olennaisesta kiistanalaisuudesta, mistä syystä Gallie esittää vielä kaksi lisäehtoa. Hieman yllättäen Gallie ei näe näitä ehtoja olennaisesti kiisteltyjä käsitteitä määrittävinä ehtoina vaan pitää niitä tällaisten käsitteiden jatkuvan käytön oikeuttavina ehtoina. Gallie selvittää tilannetta keinotekoisen mestaruusesimerkkinsä kautta toteamalla, että vaikka hänen olennaisesti kiisteltyjen käsitteidensä alkuperäinen määritelmänsä $\left(\mathrm{E}_{1}-\mathrm{E}_{5}\right)$ voi kattaa keinotekoisen esimerkin sisältämät tosiasiat, voi näiden tosiasioiden joukossa hyvinkin olla harhakuvitelma yhden ja saman pelin pelaamisesta (ECC, 175-6; PHU, 164). Seuraavassa esitän käsitteen jatkuvan käytön oikeuttavat lisäehdot:

E6 : Eksemplaari: Käsite tulee johtaa "alkuperäisestä eksemplaarista [exemplar], jonka auktoriteetin kaikki kilvoittelevat käsitteen käyttäjät tunnustavat” (ECC, 180; PHU, 168).
Näyttää siltä, että Gallie hyväksyy eksemplaariksi niin väljän perinteen erilaisine pyrkimyksineen (ks. alla) kuin (mahdollisesti tarkkarajaisen) yksittäisen esikuvankin.

$\mathrm{D}_{6}$ : Demokratian käsitteen käytöt vetoavat eksemplaariin eli "pitkään perinteeseen (jolloin kyse voi olla joukosta historiallisesti itsenäisiä mutta riittävän samankaltaisia perinteitä), joka koostuu vaatimuksista, pyrkimyksistä, kapinoista ja uudistuksista, joiden yhteisenä piirteenä on epätasa-arvoisuuden vastustaminen" (ECC, 186; vrt. PHU, 178). Gallien mukaan perinteen epämääräisyys ei vaikuta sen vaikutusvaltaan eksemplaarina.

$E_{7}$ : Kehittävä kilpailu: Käsitteen käytölle ominainen jatkuva kilpailu hyväksynnästä (acknowledgment) "mahdollistaa alkuperäisen eksemplaarin saavutuksen ylläpitämisen ja/ tai kehittämisen optimaalisella tavalla" (ECC, 180; PHU 168). Optimaalisuuteen vaikuttavat kilpailevien tahojen kykyjen lisäksi olosuhteiden suotuisuus ja epäsuotuisuus (ECC, 177; PHU, 165). Myöhemmässä, korjatussa esityksessään Gallie vielä tarkentaa, että vaikka optimaalista tilannetta, jota voidaan lähestyä eri tavoin erilaisten kilpailevien väitteiden kautta, ei koskaan saavutetakaan lopullisesti, olennaisesti kiistellyn käsitteen yhtenäisyys "sijaitsee" (reside) käsityksessä mahdollisesta optimista (PHU, 167).

$\mathbf{D}_{7}$ : Gallie toteaa, että länsimaille tyypillinen hyvinkin erilaisten poliittisten puolueiden välinen jatkuva kilpailu sekä nopeasti yltyvä erilaisten demokratiamuotojen ja -liikkeiden välinen kilpailu kaikissa maailman kolkissa tukee ajatusta siitä, että demokratian käsite on olennaisesti kiistelty (PHU, 178). Gallie ei kuitenkaan perustele eikä selvennä demokratian käsitteen yhteydessä sitä, miten hänen edellyttämänsä jatkuva kilpailu $\left(\mathrm{E}_{7}\right)$ johtaisi demokraattisen perinteen arvostettujen saavutusten optimaaliseen kehitykseen (olosuhteiden sallimissa rajoissa). Yleisesti ottaen eräänä hyötynä käsitteen olennaisen kiisteltävyyden tunnustamisesta voidaan hänen mukaansa pi- 
tää kiistoissa esitettyjen argumenttien tuntuvaa laadullista paranemista (ECC, 193; PHU, 188), mikä on toki vähintäänkin toivottavaa demokraattisessa yhteiskunnassa.

Kaksi jälkimmäistä ehtoa pyrkivät siis oikeuttamaan kiistanalaisen/toistuvasti kiistellyn käsitteen jatkuvan käytön, mikä tarkoittaa hyökkäävästi ja puolustavasti käytettyjen käsitteiden tapauksessa sitä, että kyseessä on aito kiista. Käsitteen (jatkuvassa) käytössä ei ole kyse sekaannuksesta silloin, kun kiistan osapuolet vetoavat samaan auktoritatiiviseen eksemplaariin $\left(E_{6}\right)$ ja pyrkivät edistämään ja kehittämään kyseisen eksemplaarin ilmentämää arvostettavaa saavutusta optimaalisesti $\left(\mathrm{E}_{7}\right)$. Gallie ei kuitenkaan suoraan esitä mitään sellaista ehtoa, että kiistan osapuolten tulisi kiistää ybden ja saman käsitteen asianmukaisia käyttötapoja, vaikka tämän tulisi varsin itsestään selvästi olla minkä tahansa olennaisesti kiistellyn käsitteen märitttelyn ja tunnistamisen lähtökohtana. Sen sijaan "jatkuvan" käytön oikeuttamisen tarve on omiaan herättämään kysymyksen Gallien teorian yhteiskunnalliseettisestä sidonnaisuudesta oikeuttamisen viitatessa eriävien mielipiteiden legitimointiin. Voivatko mitkään käsitteet olla olennaisesti kiistanalaisia/kiisteltyjä irrallaan yhteiskunnallisesta järjestyksestä ja arvoilmapiiristä, joka legitimoi kyseisten käsitteiden jatkuvan, toiset käyttötavat kiistävän käytön? Onko käsitteiden oletettu syvä kiistanalaisuus kulttuurillinen piirre, jota Gallie virheellisesti pitää käsitteiden sisäsyntyisenä, loogisena piirteenä?

Yksikään Gallien esittämistä ehdoista ei ole säästynyt vastaväitteiltä vuosien varrella, mutta neljä ensimmäistä ehtoa on erinäisin varauksin yleisesti hyväksytty kuvaamaan käyttämiemme käsitteiden tiettyjä ominaispiirteitä. Kolmen jälkimmäisen ehdon merkitys ja suhde edeltäviin ehtoihin on sen sijaan herättänyt enemmän kysymyksiä. Jotta Gallien teorian alkuperäistä muotoilua sekä siitä käytyä keskustelua voitaisiin hahmottaa yleisemmällä tasolla, on ensin huomattava, että ehdot vaihto- ehtojen tunnustamisesta $\left(\mathrm{E}_{5}\right)$, alkuperäisestä eksemplaarista $\left(\mathrm{E}_{6}\right)$ sekä kehittävästä kilpailusta $\left(\mathrm{E}_{7}\right)$ näyttävät viittaavan käsitteiden sisäisten ominaisuuksien ulkopuolelle ${ }^{8}$. Toiseksi Gallien puhe kiistelemisen olennaisuudesta ja hänen sanavalintansa"olennaisesti" (essentially) ovat ohjanneet tulkintoja suuntaan, jossa olennaisuuden ei katsota märïttävän kiistämisen tapaa eikä astetta vaan sen ajatellaan rajaavan kiistellyn käsitteen essentian, olemuksen. Tästä näkökulmasta kolme jälkimmäistä ehtoa näyttävät helposti virheellisiltä, harhaanjohtavilta tai triviaaleilta "itse asian" kannalta.

Gallien seitsemän ehdon määritys vaikuttaa ilmeisen kaksijakoiselta, mikä mahdollistaa toisistaan selvästi eroavat tulkinnat. Tämän kaksijakoisuuden ymmärtäminen on ensisijaisen tärkeää pyrittäessä hahmottamaan Gallien käsitystä sekä sen pohjalta esitettyjä vaihtoehtoisia näkemyksiä olennaisen kiistanalaisuuden ilmiöstä. Käsittelen seuraavaksi Gallien teorian yleisiä tulkintalinjoja aloittaen tulkintakehyksestä, joka on hallinnut keskustelua tähän päivään saakka.

\section{KÄSITTEIDEN SISÄISET}

OMINAISPIIRTEET

Kutsun Gallien teorian käsitekeskeiseksi tulkintalinjaksi näkökulmaa, jossa käsitteiden kiistanalaisuuden alkusyyksi nähdään jokin käsitteen sisäsyntyinen ominaisuus/piirre tai tällaisten ominaisuuksien/piirteiden yhdistelmä. Kyseisen metodisen kehyksen puitteissa on perusteltua analysoida yksinomaan käsitteitä, käsitteiden sisäsyntyisiä ominaisuuksia ja käsitteiden välisiä suhteita "erillään" muista käsitteiden kiisteltävyyteen vaikuttavista tekijöistä, kuten sosiaalisesta tilanteesta tai yhteiskunnallisista olosuhteista. Termi "olennaisesti” viittaa tällöin usein käsitteiden syvimmän olemuksen kiistanalaisuuteen'. Käsitekeskeiset tulkinnat keskittyvät tyypillisesti Gallien 
neljän ensimmäisen ehdon (arvottavuus, monimutkaisuus, moninainen kuvailtavuus, avoimuus) tarkasteluun kiistanalaisuuden aiheuttajana. Jokin Gallien alkuperäisistä ehdoista voidaan kuitenkin katsoa asiaankuulumattomaksi tai ehtojen kattoala jäsennetään toisin. Mikäli erityinen olennaisesti kiisteltyjen käsitteiden joukko on todella tunnistettavissa, tulisi pystyä osoittamaan, mitkä käsitteiden ominaispiirteet ja kyseisiä ominaispiirteitä kuvaavat ehdot riittävät selvästi erottamaan olennaisesti kiistellyt käsitteet muista käytetyistä käsitteistä ${ }^{10}$.

On ensisijaisen tärkeää kiinnittää huomiota verbin modaliteettiin puhuttaessa käsitteen kiistanalaisuudesta. Gallien käyttämä ilmaisu "kiistelty" (contested) antaa ymmärtää käsitteen olevan aktuaalisesti kiistelty joko nyt tai tulevaisuudessa. "Kiistanalainen" (contestable) sen sijaan viittaa mahdolliseen kiisteltävyyteen synnyttäen ajatuksen käsitteen ominaispiirteestä (tai ominaispiirteistä), joka voi aiheuttaa kiistan jonain tulevana ajankohtana. Näitä kahta käyttötapaa ei tule sekoittaa keskenään, vaikka niillä usein operoidaan ikään kuin ne olisivat samamerkityksisiä. Olennaisesti kiistellyn käsitteen tunnistamiseksi tarvitaan jokin periaate, jonka avulla kiistan alkusyy paikallistetaan joko käsitteeseen itseensä tai johonkin taustalla vaikuttavaan ei-käsitteelliseen eroon, joka johtaa osapuolten väliseen erimielisyyteen tai pitää sitä yllä. Jälkimmäisessä tapauksessa käsitteellinen kiistely on lopputulos tai seuraus ei-käsitteellisestä erimielisyydestä sen sijaan, että käsitteellinen kiistanalaisuus saisi aikaan itse kiistan. (Ks. erit. Clarke 1979, 123-4.) Esitetty erottelu on hyödyllinen Gallien seitsemän ehdon kuvauksen kaksijakoisuuden ymmärtämisessä. Karkeasti sanottuna: neljä ensimmäistä ehtoa kuvaavat käsitteellistä asiantilaa, josta kiistely seuraa, siinä missä kolme jälkimmäistä ehtoa viittaavat ei-käsitteelliseen erimielisyyteen kiistelyn aiheuttajana ${ }^{11}$.

Käsitteen olennaisen kiistanalaisuuden kriteeriksi ei kelpaa sen käyttöjen tai ilmenemismuotojen kulttuurillinen ja historiallinen moninaisuus, vaikka olisikin houkuttelevaa ajatella kyseinen moninaisuus jonkinlaiseksi todisteeksi käsitteiden perimmäisestä kiistanalaisuudesta. Tällöin moninaisuuden katsottaisiin olevan suora seuraus käsitteellisen tason kiistanalaisuudesta ${ }^{12}$; esimerkiksi termin "demokratia" moninaista käyttöä voitaisiin pitää todisteena käsitteen olennaisesta kiistanalaisuudesta tai kiisteltävyydestä. Kaikki merkittävät kiistanalaisuusväittämät menevät kuitenkin tätä heikkoa ja epäkiinnostavaa vaihtoehtoa pidemmälle (Gray 1977, 338). Olennaisen kiistanalaisuuden ilmiöstä kiinnostuneen johtoajatuksena tulisikin olla seuraava:"Nämä erityispiirteet, jatkuvasti käytävä väittely, ovat käsitteen todellista ydintä: väittely on sen elämää, ei sen kontingentti ominaisuus" (Gellner 1974, 95-6; vrt. Besson 2005, $72,74)$. Toisaalta käsitettä voi pitää olennaisesti kiistanalaisena, vaikka siitä ei aktuaalisesti kiisteltäisikään. Käsitteen luonteesta tai rakenteesta voi seurata käsitteen asianmukaisen tulkinnan kiistanalaisuus, vaikka kyseinen käsite tulisikin kiistellyksi ainoastaan yhteiskunnallisten ja poliittisten olosuhteiden niin salliessa. (Mason 1993, 58-9; Freeden 1996, 60.) Näin argumentoitaessa käsitteellä ajatellaan olevan jokin sisäinen ominaisuus, joka "pitää yllä" käsitteen jatkuvaa, potentiaalista kiistanalaisuutta, vaikka aktuaalinen kiistely käsitteestä tai sitä koskeva hetkittäinen sopu (vrt. Care 1973; PHU, 159) vaihtelevat kontingentteina asiantiloina ${ }^{13}$.

Olennaisesti kiistanalaisten käsitteiden asema kiistelyn kohteena on ongelmallinen myös itse kiistan mielekkyyden näkökulmasta. Jotta kiistelevien osapuolten voidaan sanoa puhuvan samasta asiasta, eli kiista on aito, tulee erimielisten osapuolten jakaa kiistelyn kohteena oleva käsite. Gallien ratkaisu kiistan aitouden varmistamiseksi on, että kiistanalaista käsitettä koskevat tulkinnat johdetaan kiistan osapuolten yhteisesti tunnustamasta eksemplaarista. Tämä tekee kuudennesta ehdosta (eksemplaari) monimerkityksisen, sillä tällöin ei ole selvää, onko kuvatussa käsitteiden kiistan- 
alaisuudessa kyse alkuperäisen eksemplaarin vai siitä johdettujen käsitysten kiistanalaisuudesta (Besson 2005, 74) ${ }^{14}$. Mikäli vaatimus eksemplaarista ei riitä takaamaan kiistojen aitoutta, herää kysymys, kuinka käsite voidaan jakaa, kun käsitettä pidetään samaan aikaan olennaisesti kiistanalaisena?

Olennaisen kiistanalaisuuden ilmiössä voi toki olla myös kyse jaettujen käsitteiden soveltamiseen liittyvistä hankaluuksista. Gallie ei varsinaisesti huomioi mahdollisuutta, jossa käsitteen käyttäjät jakavat käsitteen merkityksen, mutta ratkeamattoman tuntuinen kiista koskee kyseisen käsitteen soveltamista käytännössä. Tämän on katsottu seuraavan siitä, että hän ei erota arvoja ja normeja koskevaa arvottavuutta käsitteen merkityssisällön ja soveltamisalueen arvioinnista; hän sisällyttää molemmat aspektit termiin "arvottava" (appraisive). Gallien huomio on lähestulkoon yksinomaan moninaisten arvojen ja normien pohjalta tehtyjen eriävien käsitteen kuvausten tärkeysjärjestykseen laittamisessa - käsitteen ansioksi lukeman arvostetun saavutuksen eri kriteereiden tai piirteiden arvioinnissa - sekä siitä seuraavissa ratkeamattomissa kiistoissa. Hän pistää merkille käsitteen kuvausten moninaisuuden (vrt. §2: $\mathrm{E}_{2}$ ja $\mathrm{E}_{3}$ ), mutta jättää käsitteen intensiota koskevat pohdinnat puolitiehen, mitä on pidettävä selvänä puutteena ${ }^{15}$. Valittu lähestymistapa toisaalta korostaa sitä, ettei käsitteen soveltamisen hankaluus seuraa yksinomaan termin referentiaalisen merkityksen kiinnittämiseen liittyvistä ongelmista. Erimielisyys ja epävarmuus eivät rajoitu kielellisten normien puitteisiin, vaan ne koskevat lisäksi moraalisia ja poliittisia arvoja sekä normeja laajemminkin (Besson 2005, 76). Näin on erityisesti puhuttaessa moraalisista käsitteistä, kuten reiluus ja oikeudenmukaisuus, joiden täyden vahvuuden tavoittaminen vaatii käsitteiltä abstraktisuutta, joka puolestaan mahdollistaa lukuisia käsityksiä kyseisestä käsitteestä (Dworkin 1978, 103; Besson 2005, 76). Ollakseen olennaisesti kiistanalaisia käsitteitä Gallien tarkoittamassa mielessä, täytyy kyseisenlaisten (abstraktien) käsitteiden mahdollistaa lukuisia toisilleen vastakkaisia käsityksiä, joiden asettaminen toinen toistaan vastaan on täysin järkeenkäypää ja rationaalista. Vaikka kyseenalaistetuksi ja kiistellyksi muodostuvatkin tällöin käsitteestä johdetut käsitykset itse käsitteen sijaan, voidaan kiistanalaisuus nähdä kenties käsitteen (latentiksi) olennaiseksi ominaispiirteeksi. Tämä saattoi olla myös yhtenä Gallien kantavana ajatuksena teesiin Philosophy and Historical Understanding -kirjassa (1964) tehdyssä lisäyksessä. Lisäyksen mukaan olennaisesti kiistellyn käsitteen yhtenäisyys sijaitsee käsityksessä mahdollisesta optimista, vaikka optimaalista tilannetta, jota voidaan lähestyä eri tavoin erilaisten kilpailevien väitteiden kautta, ei koskaan saavutetakaan lopullisesti (PHU, 167; §2, $\mathrm{E}_{7}$ ). Käsitys mahdollisesta optimista on tällöin jonkinlainen abstrakti ideaali ${ }^{16}$.

Erilaisia muodollisia argumentteja käsitteiden olennaista kiistanalaisuutta vastaan on esitetty paljon juuri käsitekeskeisestä näkökulmasta (ks. mm. Gray 1977; Clarke 1979; Ricciardi 2000; Rhodes 2000; Newey 2001); käsiteanalyyttiset puolustukset ja edelleenkehittelyt ovat sen sijaan jääneet selvästi vähempilukuisiksi (mm. Connolly 1993/197477; Swanton 1985; Freeden 1996). Kaikki nämä argumentit ovat monimutkaisia ja analyyttisestä otteestaan ja pyrkimyksestään huolimatta varsin tulkinnanvaraisia. Ideologiatutkijana tunnetuksi tullut Michael Freeden onkin sittemmin vedonnut, että "poistakaamme [olennainen kiistanalaisuus] tuloksettomien logiikkapelien filosofiselta areenalta [...]" (Freeden 2004, 7, hakasulkeet lisätty), jotta sisällöllisistä kysymyksistä voitaisiin jälleen keskustella (vrt. Gray 1977, 345). Oli teknisistä argumenteista, niiden tehtävästä ja arvosta sitten mitä mieltä tahansa voi niistä irrottauduttuaan helposti huomata, ettei edes kaikkein vakuuttavimmilla käsitteiden olennaisen kiistanalaisuuden mahdottomaksi, mielettömäksi tai pragmaattisesti epätoivottavaksi asiantilaksi todenneilla puheenvuoroilla ole ollut tavoiteltua vaikutusta. Yhä edelleen tutkijat väittävät 
mitä erilaisimpia käsitteitä olennaisesti kiistanalaisiksi tai kiistellyiksi ${ }^{18}$. Tämä voi toki johtua tietämättömyydestä tai perehtymättömyydestä, mutta luultavaa kuitenkin on, että ajatus olennaisesta kiistanalaisuudesta on houkutteleva myös sellaisista syistä, joita käsitekeskeisestä näkökulmasta ei voi tyydyttävästi artikuloida. Tällöin Gallien väite käsiteanalyyttisen lähestymistavan riittämättömyydestä voi hyvinkin olla pitävä, ja käsitekeskeisen teesin muotoilun epäonnistuminen voi toimia siitä eräänlaisena prima facie todisteena.

Vuoden 1964 korjatussa esityksessään Gallie ei enää aiempaan tapaan painota neljää ensimmäistä ehtoa "tärkeimpinä välttämättöminä ehtoina, joita jokaisen olennaisesti kiistellyn käsitteen tulee noudattaa" (ECC, 172). Nyt "kyseiset neljä ehtoa riittävät selittämään, kuinka ja miksi sellainen tilanne voisi syntyä" (PHU, 161), jossa eri katsojaryhmät kannattaisivat ja kommentoisivat suosikkijoukkueittensa peliesityksiä. Yleisesti ottaen Gallien myöhemmät korjaukset ja painotukset ovat jääneet varsin vähälle huomiolle, vaikka niiden tarkoituksena on nähdäkseni ollut muuttaa teoriaa suuntaan, jossa sitä ei enää voitaisi pääasiallisesti pitää olennaisesti kiisteltyjen käsitteiden määritelmänä vaan tilannesidonnaisen ilmiön kuvauksena (vrt. esim. ECC 175 ja PHU 163). Seuraavissa kolmessa osiossa esitän kussakin yhden yleisluontoisen lähestymistavan ja tulkintakehyksen, jonka puitteissa ilmiöön liittyviä sisällöllisiä kysymyksiä voi analysoida ei-käsitekeskeisestä näkökulmasta.

\section{SOSIAALISTEN SUHTEIDEN}

\section{RAKENTUMISEN LOGIIKKA}

Olennaisesta kiistanalaisuudesta puhuttaessa käsitekeskeistä näkökulmaa pidetään usein itsestään selvänä lähtökohtana. W. B. Gallien alkuperäinen tapa jäsentää asiaa tarjoaa kuitenkin erinomaiset puitteet hedelmällisille avauksille, jotka kykenevät nähdäkseni selventämään olennaisen kiistanalaisuuden ilmiötä edellä esitettyä paremmin ${ }^{19}$. Seuraavassa selvitän lyhyesti perusteita ilmiön analyysille sosiaalisessa tulkintakehyksessä, siis sosiaalisten mekanismien, rakenteiden ja suhteiden puitteissa.

Edellisessä osiossa esitin, että "kiistanalainen" viittaa käsitteen kiistämiseen sen sisäisten ominaispiirteiden nojalla, mutta "kiistelty" käsite on aktuaalisesti kiistetty jostain muusta kuin käsitteellisestä syystä. Lisäksi nostin esiin muutamia syitä, miksi teesiä olennaisesta kiistanalaisuudesta ei kenties tulisi pyrkiä jäsentämään käsitekeskeisessä tulkintakehyksessä - ainakaan, mikäli halutaan tavoittaa Gallien alkuperäinen näkemys ilman huomattavia muutoksia ${ }^{20}$. Mitä kiistely itse asiassa koskee ja mihin "olennaisuudella" viitataan? Entäpä jos termiä "olennaisesti" ei tulisikaan nähdä viittauksena käsitteen olemuksen tai ytimen kiistanalaisuuteen, vaan sen tarkoituksena on korostaa itse kiistelyn/kiistämisen tärkeyttä, merkitystä ja perustavuutta? Tarvitsemme tällöin jonkin ei-käsitteellisen periaatteen olennaisesti kiisteltyjen käsitteiden tunnistamiseksi ${ }^{21}$.

John Grayn mukaan käsitteen tunnistaminen olennaisesti kiistellyksi vaatii paikkansapitävää tietoa sosiologisista ja historiallisista konteksteista sekä toistuvista tilanteista ja käytännöistä, joissa itse käsitettä käytetään. Hän kuitenkin pitää selvänä, ettei olennaisesti kiisteltyjä käsitteitä voi tutkia tarkastelematta yhteiskunnallisen muutoksen eri ulottuvuuksia (kielellisiä ja käsitteellisiä, esimerkiksi). Polemiikki ja riitaisuus, jotka koskevat sellaisia käsitteitä kuin "oikeudenmukaisuus", "demokratia" ja "vapaus", ilmentävät erimielisyyttä, joka on yhtä aikaa käsitteellistä ja sisällöllistä. Huomio on tällöin käsitteiden sisäisten ominaisuuksien sijaan ajattelumallien ja erilaisten sosiaalisten ryhmien välisissä käsitteellisissä ja empiirisissä yhteyksissä. Sisällölliset filosofiset ongelmat voidaan näin ollen saada taas tutkimuksen keskiöön. (Gray 1977, 336-7, 
345; 1978, 391.) Kiistoissa ilmenevien (sisällöllisten) ongelmien "erilaiset ratkaisut määrittävät osittain eriäviä ajattelumalleja, joiden olemassaolosta erityisiä käsitteitä koskevat määritelmälliset kiistat kielivät" (Gray 1977, $345)^{22}$. On luontevaa ajatella, että "laajemmat ajattelumallit" joutuessaan törmäyskurssille kiistoissa synnyttävät yhä uusia ongelmia, joiden vastaukset ja ratkaisut puolestaan vaikuttavat ajattelumallien rakenteeseen.

Kiistan ja kiistelyn olennaisuudesta ei ole syytä puhua kevyesti. "Olennaisuus" implikoi muun muassa merkittävyyttä, ensisijaisuutta ja välttämättömyyttä23. Kun ilmiötä tarkastellaan käsitekeskeisen näkökulman sijaan nimenomaan sosiaalisesta näkökulmasta, puhe kiistanalaisuuden olennaisuudesta asettuu hyvin erilaiseen kehykseen. Se voi kätkeä metafyysisen väitteen, jonka mukaan "juuri ihmisluonnon epämääräisyys ja osittainen määrittämättömyys on asia, joka konstituoi inhimillistä, sosiaalista elämää” (Gray 1978, 402). Toisaalta käsityksessä olennaisesta kiistanalaisuudesta ei ole niinkään kyse reaalista tai ulkoista maailmaa koskevasta väitteestä; kyse on epistemologisista, psykologisista ja loogisista rajoitteista tuon maailman jäsentämisessä ja ymmärtämisessä (Freeden 1996, 59). Aktuaalinen kiistely seuraa tällöin kyseisistä rajoitteista. Jotta voitaisiin puhua olennaisesta kiistanalaisuudesta sosiaalisen tulkintalinjan puitteissa, tulee nämä epistemologiset, psykologiset ja loogiset rajoitteet nähdä inhimillistä ajattelua ja ymmärrystä olennaisesti ohjaavina, ei esteinä, joiden poissa ollessa viime kädessä oikea vastaus voitaisiin periaatteessa saavuttaa.

Hankalat ja syväluotaavat käsitteelliset sekä sisällölliset kiistat voivat siis seurata inhimillisistä ajattelumalleista yhteiskunnallisten olosuhteiden ollessa suotuisat ${ }^{24}$. Tällöin inhimilliset ajattelumallit johdetaan ihmisluonnon piirteistä, inhimillisistä vakioehdoista (buman condition) ja/tai sosiaalisten suhteiden rakentumisen logiikasta ${ }^{25}$, mikä vaatii tuekseen metafyysisiä tai sosiaaliontologisia väitteitä (jotka ovat toki kritisoitavissa ja kiistettävissä).
Vaikkei kyse nyt enää olekaan käsitekeskeisen näkökulman "kiistanalaisuudesta" contestable-mielessä, tulevat käsitteet kiistetyiksi contested-mielessä osana prosessia, jota voidaan pitää epäilemättä "olennaisena" inhimilliselle ja sosiaaliselle toiminnallemme. Näin siis, mikäli inhimilliset ajattelumallit, jotka saavat mainitunlaisia käsitteellisiä kiistoja aikaan, todellakin seuraavat ihmisluonnon piirteistä, inhimillisistä vakioehdoista ja/tai sosiaalisten suhteiden rakentumisen logiikasta. Tällöin itse kiistaa ja kiistelyä pidetään olennaisena, ei niinkään jonkin tietyn käsitejoukon kiistanalaisuutta. Gallie ei toki esitä alkuperäistä teesiään tällä tavoin. Myöskään sosiaaliseen tulkintakehykseen sopivia avauksia, joissa olennaisen kiistanalaisuuden teesiä pyritään Gallien lähtökohdista kehittämään eteenpäin, ei ole juuri tehty.

David-Hillel Rubenin $(2010 ; 2013)$ tulkintaa voitanee pitää edellisen suhteen poikkeuksena, ja sitä voidaan nyt käyttää yhtenä esimerkkinä. Rubenin mukaan Gallie oli kiinnostunut siitä, kuinka kiistan osapuolet voivat oikeutetusti väittää olevan jonkin aiemman poliittisen, uskonnollisen tai esteettisen näkökulman tai sen pohjalta muodostuneen tradition tosia tai autenttisia seuraajia tai myöhempiä edustajia ${ }^{26}$. Ruben myös väittää, että Gallien merkittävimmät huomiot voidaan käsitellä lähestulkoon ilman yhtään viittausta "käsitteen käsitteeseen, puhumattakaan käsitteen käsityksestä" (Ruben 2010, 261). Ilmiön analysoinnissa keskitytään tällöin "tosiseuraajuuteen" (true succession) ja "oikeanlaiseen uskollisuuteen" (faithfulness) tai jäsenyyteen (membership) traditioissa, jotka ajan kuluessa haarautuvat useisiin alatraditioihin. Viime kädessä kiistojen ratkeamattomuuden saa aikaan se, ettei kysymystä eksemplaarin oikeanlaisesta tosiseuraajuudesta voida ratkaista kiistelijöiden antaessa eri painoarvon tradition piirissä edistettävän arvostetun saavutuksen eri piirteille tai osa-alueille. Tällöin ei voida (kiistattomasti) arvioida tai laskea, kenen uskomukset ja 
käytännöt ovat laadullisesti samankaltaisimpia eksemplaarin kanssa. Tällaisten kiistojen hankaluus ei koske niinkään vaikkapa demokratian tai kristillisyyden ideaa. Pikemminkin ajatuksemme traditioiden jäsenyydestä on hämärä. (Ruben 2010, 257, 263, 267-70.) Rubenin käsitys osoittaa mainiosti, kuinka Gallien alkuperäisen teorian puitteissa olennaisen kiistanalaisuuden luonnehtiminen ei-käsitekeskeisestä näkökulmasta on täysin mahdollista. Huomionarvoista on, ettei tällöin myöskään tarvitse suorilta käsin luopua kahdesta viimeisestä ehdosta, eksemplaarista ja kehittävästä kilpailusta, kuten käsitekeskeisissä tulkinnoissa päädytään usein tekemään. Sosiaalisen tulkintakehyksen etuna on tavoittaa uusia ja hyvin relevantteja piirteitä itse kiistan luonteesta sulkematta ovia muilta mahdollisilta (esim. puhtaasti kielellisiltä) kiistojen syiltä, joita ei kuitenkaan katsota olennaisen kiistanalaisuuden syiksi.

Tämän osion lopuksi nostan vielä esiin muutaman seikan, jotka puhuvat sosiaalisen tulkintakehyksen puolesta. Erityisesti yhteiskuntatieteille vaikuttaa olevan ominaista, ettei lopullisia vastauksia kysymyksiin, jotka edellyttävät yhteiskunnallista elämää koskevien yleistysten tekemistä, ole saatavilla. Alasdair MacIntyre on muiden muassa todennut, ettei tietyillä yhteiskunnallisen tutkimuksen osa-alueilla kiisteltävyys taukoa edes hetkellisesti tai väliaikaisesti, mikä kenties kielii olennaisesta kiistanalaisuudesta ${ }^{27}$. Yhteiskunta- ja ihmistieteet eivät nimittäin tarjoa tarttumapintaa sen määrittelemiseen, mitkä ovat normaaleja tai standardisoituja olosuhteita ja ehtoja, joiden puitteissa voitaisiin päästä väliaikaiseen sopuun avoimista käsitteistä. (MacIntyre 1973, 1-3.) Tätä ei tule kuitenkaan ymmärtää jyrkästi niin, etteivät käsitteitä koskevat aktuaaliset väliaikaiset sovut (temporary closures) olisi lainkaan mahdollisia; ne ovat itse asiassa varsin tavallisia myös yhteiskuntatieteissä (Care 1973; vrt. mt. 9). Tutkimuksen osa-alueet, joihin MacIntyre viittaa, koskevat toimintaa ja käyttäytymistä osana sosiaalisia ryhmittymiä, instituutioita ja käytäntöjä. Näissä tapauksissa henkilöiden "uskomukset konstituoivat osittain ainakin joitakin keskeisiä yhteiskunnallisia instituutioita ja käytäntöjä, ja kyseiset uskomukset pitävät aina sisällään jonkin muunnelman kyseessä olevan instituution tai käytännön käsitteestä" (MacIntyre 1973, 3; vrt. Gray 1978, 394). Tällöin huomion kohteena olevat yhteiskunnalliset instituutiot ja käytännöt sekä niitä koskevat uskomukset ja käsitteet vaikuttavat toinen toisiinsa. Käsitteen/käytännön refleksiivinen luonne on ratkaiseva sen olennaisen kiistanalaisuuden aikaansaava tekijä. "Kyseisenkaltaisen käytännön sisäistä väittelyä ei voi erottaa käytäntöä koskevasta väittelystä, ja molemmat muodostavat osan ko. käytännöstä" (MacIntyre 1973, 6) ${ }^{28}$. Esimerkiksi" [s]itä, kuinka kategorisoimme koulutusinstituutioita, ei voi erottaa siitä, minkä normien mukaan määritämme koulutusta" (mt., 7). Tällaisten erimielisyyksien käytännön ilmentymät eivät ole erotettavissa niiden kielellisestä artikulaatiosta välttämättä edes teoreettisesti (mt., 4). Normatiivisissa kiistoissa kiistelijät jakavat tyypillisesti käsitteen merkityksen, mutta ovat eri mieltä käsitteen soveltamisesta. Olennaisen kiistanalaisuuden tapauksessa puolestaan vallitsee erimielisyys sekä olennaisesti kiistanalaisen käsitteen (arvottavista) kriteereistä että niitä vastaavista todellisuuden (kuvaavista) piirteistä ja piirteiden yhdistelmistä. Tällainen kiistanalaisuus on yhtä aikaa käsitteellistä ja sisällöllistä/normatiivista. (Besson 2005, 80-1, 88-9.) Vaikka käsite tulee kiistellyksi "ytimiään myöten”, osallistuminen jaettuun käytäntöön (esim. Rubenin traditio edellä) mahdollistaa kiistan aitouden ${ }^{29}$.

Tässä osiossa esitettyä tapaa ymmärtää olennainen kiistanalaisuus voidaan täydentää toki monin tavoin. Näin aion myös tehdä seuraavassa osiossa, jossa erittelen historiallisen tulkintalinjan piirteitä, selvittämällä käsitteiden ja käytäntöjen identiteettiä ja jatkuvuutta koskevia kiistoja. 


\section{HISTORIALLINEN YMMÄRRYS}

Politiikan käsitehistorioitsijat ovat pyrkineet lähestymään olennaista kiistanalaisuutta tavalla, jota kutsun historialliseksi. Huomiota kiinnitetään tällöin käsitteisiin ja niiden historiallisiin muutoksiin, mutta kyse ei silti ole edellä kuvatusta käsitekeskeisestä lähestymistavasta. Historiallisen tulkinnan mukaan käsitteiden olennainen kiistanalaisuus seuraa uniikkien määrittely- ja arviointistandardien puuttumisesta, oli käsitteiden perimmäinen "olemus" tai sisäinen rakenne sitten mitä tahansa. Pyrkimyksenä on täydentää analyyttisen metodin tarjoamaa synkronistista kuvausta kattavamman diakronisen näkökulman saavuttamiseksi. Mario Ricciardi (2000) tiivistää ajatuksen seuraavasti: mikäli kieli on luonteeltaan historiallista, tulisi filosofian menetelmän myös olla historiallinen. Filosofien tehtävänä on tällöin rekonstruoida erityiseen ideaan tai teoriaan johtavat geneettiset prosessit. Inhimillisiä asioita käsitellessä tarvitaan historiaa, toisin sanoen eräänlaista kollektiivista biografiaa. (Ricciardi 2000, 39; vrt. PHU, 156, 168; ks. myös Freeden 1996, 52.)

Gallien lähestymistapaa voidaan kutsua "väitteeksi historiallisen ymmärryksen ensisijaisuudesta" (mt.) ${ }^{30}$. Käsitteiden olennaisen kiistanalaisuuden selvittäminen ja niiden geneettisten kehitysprosessien seuraaminen eivät ole kuitenkaan mutkattomasti yhdistettävissä, vaikka tarkoitus olisi "vain" täydentää muuten vaillinaista ymmärrystä. On toki niin, ettei käsitteen väittäminen olennaisesti kiistellyksi takaa analyyttisten virheiden välttämistä (Waldron 2002, 152). Historiallisen tulkintatavan mahdollisuuksien selventämiseksi on syytä tarkastella yhtä mahdollista virhettä: geneettistä virhepäätelmää ${ }^{31}$.

Yleisesti hyväksytään, että käsitteen (kuten instituutionkin) nykyinen funktionaalisuus on loogisesti riippumaton sen historiasta. Näin ollen "olennaisesti kiistellyn käsitteen" tulee olla tunnistettavissa sen nykyisen toimivuuden pohjalta (Gellner 1974, 96; Gray 1978, 390). Gallien kuudennen ehdon ${ }^{32}$, eksemplaarin, tarkoitus on auttaa erottamaan olennaisesti kiisteltyjen käsitteiden käytöt mahdollisista käyttöjen välisistä sekaannuksista. Kun eksemplaari liitetään osaksi olennaisesti kiistellyn käsitteen määritelmää, olennaisesti kiistellyn käsitteen tunnistaminen onnistuu, mutta vain syyllistymällä geneettiseen virhepäätelmään ${ }^{33}$. Mikäli eksemplaari tulkitaan väljemmin laajaksi perinteeksi moninaisine pyrkimyksineen, kyse on pikemminkin ideaalista, jota myös itse aktuaalinen eksemplaari "noudattaa", kuin mistään yksittäisestä vertailukohdasta. Tällöin eksemplaari on teoreettisesti tarpeeton. (Gellner 1974, 96-97.) Äärimmilleen vietynä Gallien vaatimus alkuperäisestä eksemplaarista voidaan nähdä pyrkimykseksi postuloida jokaiselle olennaisesti kiistanalaiselle käsitteelle kiistaton ideaalikäsite, johon vetoaminen on välttämätöntä, jotta sekaannukset voidaan välttää. Gallien käsitteellinen anti-essentialismi uhkaa kiepsahtaa tällöin päälaelleen. Eksemplaarin ongelmallisuus olennaisesti kiisteltyjen käsitteiden ebtona vaikeuttaa huomattavasti Gallien alun perin esittämien ehtojen hyväksymistä sellaisenaan, kun teoria tulkitaan käsitekeskeisesti. (Mt., 99; ks. myös Gray 1978, 391-2; Freeden 1996, 60.)

Tulkintani mukaan Gallie tuntuu itse olevan tietoinen siitä, että hänen kuvaamansa kaltaiset hankalat kiistat seuraavat pitkälti muutoksista olosuhteissa eikä niinkään olennaisesti kiisteltyjen käsitteiden sisäsyntyisen luonteen vuoksi (ks. myös Syrjämäki 2011, 139). Gallie pyrki ennen kaikkea vastustamaan anti-geneettistä asennetta, siis tutkittavien kohteiden (käsitteet, instituutiot) irrottamista muuttuvista yhteiskunnallisista puitteistaan käsittämällä ne ajattomiksi ja staattisiksi (Gellner 1974, 97). Mikäli Gallie todellakin olisi tarkoittanut vaatimuksensa alkuperäisestä eksemplaarista olennaisesti kiistellyn käsitteen määritelmän osaksi siten, että eksemplaari tulisi nähdä samanlaiseksi käsitteen sisäiseksi ominaispiirteeksi kuin vaikkapa sen avoimuus, 
olisi hänen teoriansa ilmiselvästi virheellinen tai vähintäänkin hyvin sekava. Nähdäkseni tälle tulkinnalle ei ole juurikaan perusteita (vrt. ECC, 196-7). Gallie itse toteaa, että arvottavan $\left(\mathrm{E}_{1}\right)$ käsitteen tapauksessa yksinkertaisesti voimme ymmärtää paremmin, mitä käsite tarkoittaa, kun vertaamme käsitteen nykyistä käyttöämme toisiin mahdollisiin käyttöihin (ECC, 198). Voitaneen siis ajatella, että käsite on alimäärittynyt ilman kulttuurillista ja historiallista kontekstiaan, siis että käsitteestä jää aina puuttumaan jotain olennaista ilman sen historiallista tai kulttuurillista sidonnaisuutta.

Toisin kuin luonnontieteiden tapauksessa, yhteiskuntatieteiden piirissä törmätään tyypillisesti havaintoon, ettei tiettynä hetkenä käypiä käsitteitä ole mahdollista soveltaa luotettavasti myös tulevaisuudessa ja tulevissa tapauksissa. Monien yhteiskunnallisten yksilöolioiden, kuten esimerkiksi poliittisten puolueiden, identiteetistä puhuttaessa ei lainkaan viitata näiden olioiden lainalaisuuteen, toisin kuin luonnontieteellisiä käsitteitä käytettäessä ${ }^{34}$. Yhteiskunnalliset yksilöoliot muuttuvat sen mukaan, mikä käsityksemme niistä on. Institutionalisoituneen perustelun, väittelyn ja konfliktin jatkuvuus on osa yhteiskunnallisten käytäntöjen ja organisaatioiden jatkuvuutta ja identiteettiä. Refleksiivisyys ei ilmene yksinomaan käsitteiden ja käytäntöjen synkronisessa arvioinnissa ja on vähintäänkin yhtä olennainen tekijä kuin identiteetin jatkuvuus. Se saa aikaan jyrkkiä katkonaisuuksia ja epäyhtenäisyyksiä instituutioiden ja käytäntöjen historiassa, mikä mahdollistaa perusteellisen käsitteellisen innovaation. (MacIntyre 1973, 4-6.) Yhteiskunnallisten yksilöolioiden identiteetti ja jatkuvuus eivät siis määräydy jyrkän sosiaalisesti ja/tai geneettisesti.

Edellä esitetty näkökulma olennaiseen kiistanalaisuuteen ei välttämättä ole tarpeek$s i$ historiallinen. Eikö ole pikemminkin niin, että käsitteen empiirinen kiistettävyys aikojen kuluessa on sittenkin seurausta joistain olennaisista ja perustavista yhteiskunnallisista prosesseista ja/tai ihmissuhteiden mekanismeista?
Kiistelyn välttämättömyydestä seuraisi siten käsitteiden asema olennaisesti kiisteltyinä (ks. §4). Puhe käsitteiden historiallisesta luonteesta tai historiallisesta ymmärryksestämme olennaisen kiistanalaisuuden aiheuttajana voi olla siis tässä mielessä harhaanjohtavaa. Sosiaalisten prosessien ajallisen jatkuvuuden korostaminen ei vielä riittävästi erota historiallista tulkintakehystä sosiaalisesta.

Käsitteiden kiistanalaisuus voidaan nähdä historiallisesta kontekstistaan riippuvaksi kahdella tapaa ${ }^{35}$. Ensimmäisessä näkemyksessä hylätään evolutiiviset oletukset ideoiden historiallisuudesta ja todetaan käsitteiden ajallinen muuttuminen kiistattomaksi tosiasiaksi. Tällöin käsitteellinen määrittelemättömyys liitetään edelleen empiirisiin olosuhteisiin eikä käsitteissä ole luontaisesti mitään, mikä selittäisi vakiintuneiden määritelmien horjumisen. Historiallisuus ei siis konstituoi käsitteitä, vaikka käsitteet toki ajan kuluessa muuttuvatkin. Käsitteet ovat kiisteltyjä, mutta eivät olennaisesti kiistanalaisia. (Palti 2005, 116; vrt. PHU, luku 7.) Toisessa ja vahvemmassa käsityksessä kontingenttiuden tai kiistanalaisuuden alkusyy löydetään intellektuaalisesta historiasta itsestään, jolloin käsitteiden merkityksen märitttelemättömyyttä ei enää todenneta empiiristen tosiasioiden perusteella. Käsitteiden ja käsiteryvästen luonteesta johtuen niiden semanttista sisältöä ei voi kaikilta osin jäsentää ja tuoda esiin rationaalisesti sekä loogisesti (vrt. PHU, 155).

Ymmärtääksemme, miksi jokaisen käsitteen merkityksen kiinnittäminen voi olla konstitutiivisesti hataralla pohjalla, täytyy käsitteiden historiasta siirtyä poliittisten diskurssien historiaan. Tällöin ei ainoastaan pyritä jäljittämään yksittäisten käsitteiden muutoksia vaan myös selittämään, miksi kyseiset käsitteet eivät täydellisty semanttisesti (Palti 2005, 116-7). Elías Paltin vastaus kysymykseen "miksi käsitteet eivät täydellisty semanttisesti?" on lyhykäisyydessään seuraava: modernit, poliittiset diskurssit ovat konstitutiivisesti epätäydellisiä eivätkä koskaan loogisesti integroituja ja yh- 
tenäisiä entiteettejä. Näiden diskurssien ytimen muodostaa antiikkisten kosmologioiden jälkeinen maailmankatsomuksellinen tyhjyys, mikä on viime kädessä syy siihen, ettei yksikään moderni, poliittinen kategoria voi vakiinnuttaa merkitystään ${ }^{36}$. Käsitteiden uudet märitelmät kykenevät horjuttamaan annettua poliittista diskurssia ainoastaan osoittamalla sen sokeat pisteet,"tyhjyyden, joka sijaitsee sen keskuksessa" (mt., 131). Aiemman hegemonisen diskurssin korvaava uusi diskurssi lepää kuitenkin tyhjyyden päällä yhtälailla. Kiistanalaisuudesta tekee lopulta olennaisen se, ettei paluuta entisiin lujaa maata jalkojen alle tarjoaviin merkityksiin enää ole. Tämän väitteen todentaminen voi kuitenkin olla hyvin vaikeaa, sillä tosiasiallinen kiistely kyseisten diskurssien puitteissa ei vielä riitä osoittamaan kiistanalaisuuden olennaisuutta periaatteellisella tasolla.

\section{KIISTANALAISUUS POLIITTISEN}

\section{OLENNAISENA PIIRTEENÄ}

Olennainen kiistanalaisuus voidaan siis nähdä historiallisesti määrittyneen poliittisen kielenkäytön olennaiseksi piirteeksi. Näin ollen herää varsin luonteva ajatus, että kyseessä on ennen muuta poliittinen ilmiö, ja useammassa kuin yhdessä mielessä näin varmasti onkin. Politiikan alan erityistieteiden näkökulmasta kysymys kiistanalaisuuden olennaisuudesta näyttäytynee kuitenkin ennen kaikkea pragmaattisena, ja perustava käsitteellinen kiistanalaisuus on nähtävissä politiikan alan ilmiöiden välttämättömäksi edellytykseksi.

Näkemykset syvän konfliktin ja kiistanalaisuuden asianmukaisesta painoarvosta ja roolista politiikan teoriassa ja tutkimuksessa vaihtelevat verrattain paljon. Erityisesti normatiivisen poliittisen filosofian ja kontingenssia ja eroa korostavan poliittisen teorian välinen vastakkainasettelu ilmenee toisinaan tässä suhteessa hyvin selvästi. Pyrkimys poistaa kiis- tanalaisuus poliittisen tutkimuksen termistöstä voidaan nähdä jopa haluna paeta politiikkaa. Samalla politiikan arvoa alennetaan, kun sen erityisluonne ohitetaan ja/tai poliittiset vaikutukset jätetään teoretisoinnin ulkopuolelle metodologisin perustein. (Connolly 1993, 213; myös Mouffe 2005.) Universaalisuuteen pyrkivää normatiivista filosofiaa on myös kritisoitu teorian ja (partikularistisen) ideologian rajan häivyttämisestä irrottamalla ne diakronisesta perinteestä. Historiallisesti sidonnaiset ideologiat (tässä "ideoiden järjestykset") muodostuvat tietynlaisiksi sen mukaan, mitkä ovat ne käsitteet, joista ideologiat koostuvat, ja missä suhteessa ne toisiinsa nähden ovat. (Freeden 1996.) Kiistanalaisuutta ja pysyvien erimielisyyksien olennaisuutta voidaan korostaa myös kritisoimalla suoraan yhteisymmärrykselle ja yksimielisyydelle perustuvien, tai sitä vaativien, poliittisten käsitysten teoreettista itseymmärrystä. Tällöin toiset ihmiset huomioonottavan tietoisen erimielisyyden mahdollistavien tapojen ja prosessien löytäminen ja kehittäminen voi olla monimuotoisissa yhteiskunnissa vähintään yhtä tärkeää kuin kyseisen erimielisyyden nujertaminen moraalisesti hyväksyttävällä tavalla (van den Brink 2005). Erilaisista lähestymistavoista huolimatta olennaisen kiistanalaisuuden implisiittinen hyväksyminen yhdistää huomattavan montaa nykyistä, päällisin puolin vastakkaista poliittisteoreettista käsitystä.

Keskustelu poliittisen kielen tai kielenkäytön olennaisesta kiistanalaisuudesta herättää samansuuntaisia kysymyksiä ja pohdintoja kuin aiemmin esitetty historiallinen tulkintatapa, ja näiden tulkintapojen välillä on merkittäviä yhtäläisyyksiä. Jotta poliittista tulkintalinjaa voitaisiin pitää erillisenä ${ }^{37}$, tulee sillä kuitenkin olla selvästi erotettavissa olevat ominaispiirteensä. Mitkä ne siis ovat? Ensinnäkin olennaisessa kiistanalaisuudessa on tällöin oletettavasti kyse yksittäisiä käsitteitä laajempien tai ne muilla tavoin ylittävien kokonaisuuksien kiistanalaisuudesta. Teesi olennaisesta kiistanalaisuudesta voidaan esimer- 
kiksi nähdä paikkansapitäväksi yleistykseksi poliittisesta kielestä. Poliittisen diskurssin kieli on olennaisesti kiistanalainen, kun taas ne käsitteet, joista poliittiset kielet koostuvat, ovat kontingentisti kiisteltyjä (Ball 1988, 14; 2006, n.12). Kiistämisen arvoisina pidetyt käsitteet määräytyvät tällöin pikemminkin poliittisesti kuin filosofisesti, ja havaittu peruuttamaton ja kattava erimielisyys ja kiistanalaisuus seuraavat poliittisista diskursseista ja poliittisen kielenkäytön tavoista. Käsiteltävä ilmiö ja poliittiset diskurssit ovat epäilemättä yhteydessä toisiinsa, mutta se ei vielä kerro, mitä sellaiset muotoilut kuten "poliittisen diskurssin kieli on olennaisesti kiistanalainen" (Ball 1988, 14) todella tarkoittavat. Oletettavasti kyseessä on vahva filosofinen väite kielen luonteesta, joka tulisi täsmällisesti perustella. Esitykset poliittisen kielen, kielenkäytön tai diskurssien kiistanalaisuudesta tai kiistettävyydestä jäävät kuitenkin valitettavan usein pintapuolisiksi ${ }^{38}$.

Eräs luonteva vaihtoehto on ajatella politiikkaa ja poliittista kielenkäyttöä käytäntönä, jonka mielekkyyden viimekätinen kiistanalaisuus takaa (Palti 2005, 117-8). Mikäli käsitteiden kuten vapaus, oikeudenmukaisuus ja demokratia merkitykset voitaisiin varmentaa lopullisesti ${ }^{39}$, ei politiikasta tai poliittisesta puhuminen nykyisin laajalti jaetussa (joskaan ei kiistattomassa) mielessä olisi enää mahdollista. Michael Freeden onkin esittänyt kiinnostavan muunnelman olennaisen kiistanalaisuuden ajatuksesta kutsuen sitä "toiminnalliseksi kiistanalaisuudeksi" (effective contestability). Käsite on toiminnallisesti kiistanalainen, koska sen kiistanalaisuus seuraa poliittisen diskurssin ominaispiirteistä, sen sijaan että kyseessä olisi käsitteen ominaispiirre. Tällöin käsitteen "kiistanalaisuus on toiminnallisesti bävittämättömissä [effectively ineliminable] tunnistamamme ajatuskäytännön [thought-practice] suhteen" (Freeden 2004, 5, hakasulkeet lisätty; vrt. Freeden 1996, 55). Mikäli poliittinen diskurssi lakkaisi olemasta kiistanalainen - looginen, joskin kulttuurisesti epäuskottava mahdollisuus - itse diskurssi ja sen käsitteet vakiinnutettaisiin (de- contest) tavalla ${ }^{40}$, joka eroaisi aiemmista käytännöistä sekä olisi toiminnallisesti käsittämätön minkään tulevan käytännön suhteen. Emme tunnistaisi kyseistä käytäntöä enää poliittiseksi diskurssiksi vaan kyse olisi jostain aivan muusta. Tästä seuraa Freedenin mukaan se, että toiminnallinen kiistanalaisuus on politiikan tuntijalle yhtä vahva väite kuin olennainen kiistanalaisuus on loogikolle. (Mts.) Teesi toiminnallisesta kiistanalaisuudesta on nähtävissä yritykseksi muotoilla olennaisen kiistanalaisuuden perusajatus siten, että ilmiötä koskevat intuitiot voitaisiin hyväksyä käytännöllisemmän poliittisen tutkimuksen teoreettisen itseymmärryksen osaksi.

Toiminnallinen kiistanalaisuus on varteenotettava muunnelma olennaisesta kiistanalaisuudesta. Ensinnäkään kyseessä ei ole väite, jossa yksinkertaisesti todetaan kulttuurillinen ja historiallinen variaatio todisteeksi kiistanalaisuudesta. Sen sijaan kiistanalaisuus nähdään poliittisen diskurssin olennaiseksi piirteeksi. Toiseksi täytyy todeta, että politiikan ja ideologioiden tutkijoiden näkökulmasta käsitys toiminnallisesta kiistanalaisuudesta on todennäköisesti riittävä. Tilannetta ei tosin tarvitse nähdä poliittisen ja filosofisen jyrkkänä vastakkainasetteluna. $\mathrm{Ne}$, jotka hyväksyvät toiminnallisen kiistanalaisuuden, voivat John Grayn tavoin jättää auki kysymyksen, saadaanko poliittisen filosofian "ikuisiin ongelmiin" [sic] koskaan vastausta. Kenties edistyminen muilla tieteen tai filosofian osa-alueilla tuo tulevaisuudessa selvyyttä asiaan (vrt. Gray 1977, 346-7). Vaikka kiistanalaisuutta tulee todennäköisesti ilmenemään myös tulevaisuudessa, ei tätä voi osoittaa tyhjentävästi. Tuleva väestö voi muodostaa sellaisia kielellisiä muotoja ja diskursseja, joista emme tällä hetkellä ole tietoisia. (Connolly 1993, 229.) Kolmanneksi on huomattava, että olennainen kiistanalaisuus voi olla ennen kaikkea vallitsevaa liberaalisdemokraattista, pluralistista yhteiskuntaa määrittävä piirre. Tietyssä sosiaalifenomenologisessa mielessä tämä vaikuttaa ilmeiseltä: mikäli pidämme kiistanalaisuutta poliittisen käytäntömme 
tai diskursiivisten muotojemme olennaisena piirteenä, ja tunnumme tosiaan näin tekevän, muodostamme intersubjektiivisesti jaetun sosiaalisen todellisuutemme siten, että olennainen kiistanalaisuus on tiettyjen käytäntöjen erottamaton osa.

Tarkasteltaessa erilaisia muotoiluja olennaisesta kiistanalaisuudesta on vaikea välttyä ajatukselta, että "poliittinen" alkaa siitä, mihin väitteet olennaisesta kiistanalaisuudesta päättyvät. Näin vaikuttaisi olevan erityisesti käsityksissä, joissa kiistanalaisuus nähdään toiminnalliseksi. Mikäli poliittista kiistanalaisuutta voidaan nimittää olennaiseksi ainoastaan poliittisen käytännön olennaisena osana, ei poliittisen tulkintakehyksen puitteissa annettu vastaus kysymykseen "mistä olennainen kiistanalaisuus on seurausta?" välttämättä juurikaan eroa sosiaalisen tulkinlinjan mukaisesta vastauksesta. Tämä ei kuitenkaan tarkoita, ettei kysymys olennaisesta kiistanalaisuudesta olisi politiikan tutkijoiden ja teoreetikkojen näkökulmasta kiinnostava. Asian voi nähdä niin, että tällaisissa kiistoissa on kyse (1) käsitteen senhetkisen käytön merkitystä muovaavien yhteisöllisten normien kyseenalaistamisesta; (2) siitä, mikä ryhmä onnistuu hallitsemaan kiistellyn käsitteen merkitystä; ja (3) mikä ryhmä merkityksen hallinnan myötä onnistuu asemoimaan itsensä yhteisöllisten normien vartijaksi (Boromisza-Habashi 2010). Huolimatta siitä, että tällaisen kiistanalaisuuden alkulähde paikantuu sosiaalisen tulkintakehyksen puitteissa paremmin, lienee selvää, että edellä kuvatut kiistat ovat poliittisia ja niissä on usein kyse poliittisen diskurssin hallinnasta.

Olennainen kiistanalaisuus ja pluralistinen liberalismi ovat myös yhteydessä toisiinsa, ja tätä tulen jäsentämään loppuosiossa vielä hieman tarkemmin. Käsitys olennaisesti kiistellyistä käsitteistä putkahtaa esiin moraalisessa ja poliittisessa perspektiivissä, joka käy yksiin pluralistisen liberalismin kanssa ${ }^{41}$. Erityisen hyvin tämä käy ilmi tarkastellessa niitä hyötyjä, joita Gallie väittää käsitteellisen kiistanalaisuuden tunnustamisesta seuraavan: keskustelun (ja kenties arvomaailman) laadullinen paraneminen jatkuvan dialogin seurauksena (ECC, 193). Vielä tärkeämpää on huomata, että jonkin käsitteen toteaminen olennaisesti kiistellyksi tai kiistanalaiseksi kertoo koko lailla paljon käsitteen käyttäjien muodostaman yhteisön luonteesta. Jotta kyse olisi olennaisesta kiistanalaisuudesta, tulee sosiaalisen ja poliittisen ajattelumme toimia ympäristössä, jota kiistelyn mahdollistavat seikat - esim. perusteellinen moninaisuus ja moraalinen individualismi (Gray 1977, 337) - oleellisesti leimaavat ja määrittävät.

Näin ollen voidaan ajatella, että liberalismi ilmaisee metateoreettisen väitteen, jonka mukaan "yhteensopimattomien päämäärien yhteentörmäys on poliittisen elämän muuttumaton (ja kenties myös määrittävä) piirre" (Gray 1978, 388). Liberalistista yhteiskuntaa ei kenties niinkään määritä sitoutuminen johonkin tiettyyn ideaaliin vaan sen kyky ymmärtää kilpailevia ja toisensa kyseenalaistavia ideaaleja sekä sovitella niiden erinäisiä vaateita. (Mt., 388, 395.) John Rawlsin poliittinen liberalismi (Rawls 1993) on tästä varsin hyvä esimerkki. Jürgen Habermas on puolestaan todennut, että monimuotoisissa liberalistisissa yhteiskunnissa käsitys suvaitsevaisuudesta vaatii syvissä (uskonnollisissa) kiistoissa osapuolten ymmärtävän, että on järkeenkäypää olettaa kohdatun vastustuksen ja erimielisyyden olevan pysyvä (Habermas 2006, 47, 50; vrt. PHU, 169). Olennaisen kiistanalaisuuden mahdolliset yhteydet liberalistisiin käsityksiin jäävät toki vielä hyvin pintapuolisiksi näin esitettynä ${ }^{42}$.

Olennainen kiistanalaisuus näyttää olevan läheisessä kytköksessä myös verrattain erilaisiin liberalismin muotoihin. Chantal Mouffe yhdistää ajattelussaan arvopluralismin, syvän erimielisyyden ja kiistojen rationaalisen ratkeamattomuuden näkemyksessään vapauden ja tasa-arvon periaatteista seuraavasti:"olemme eri mieltä kyseisten periaatteiden merkityksestä ja toteuttamisesta, ja tällaista erimielisyyttä ei voida ratkaista deliberaatiolla eikä rationaalisella keskustelulla. Todellakin, kun otamme 
huomioon syvään juurtuneen arvopluralismin, ei konfliktille ole rationaalista ratkaisua..." (Mouffe 2000, 101-2). Demokraattisen politiikan toimiessa "toisia" ei nähdä vihollisina vaan legitiimeinä vastustajina, joiden kanssa vapauden ja tasa-arvon periaatteita jaetusti kannatetaan (mt.). "Agonististen pelien" turvaamisen (Tully 1999; 2000) tulisi olla yhteiskuntamme keskeinen (eettispragmaattinen) tavoite. Mikäli nämä huomiot ilmentävät agonistisen liberalismin ydintä, käy kyseinen ydin erittäin hyvin yhteen Gallien alkuperäisen teorian keskeisen sisällön kanssa (vrt. ehdot $\mathrm{E}_{5-7}$; ks. myös PHU, 151-3, 156, 167). Osapuolten tulee tunnustaa, että olennaisesti kiisteltyjä käsitteitä koskevat kiistamme eivät ole rationaalisesti ratkaistavissa, mutta kiistelyä tulee tästä huolimatta silti jatkaa osapuolten kontribuutioiden ollessa (potentiaalisesti) arvokkaita ja arvostettavia. Sen, että pelaamme samaa (agonistista) peliä - eli jaamme yhden ja saman käsitteen, mutta olemme eri mieltä sen merkityksestä ja käytöstä - takaa Gallien teoriassa alkuperäisen eksemplaarin jakaminen. Saman paikan voi käsitteellisesti täyttää esimerkiksi "yhteinen symbolinen tila, jonka puitteissa konflikti tapahtuu"(Mouffe 2005, 20). Rawlsilaisessa liberalismissa mennään symbolista tilaa astetta pidemmälle "kattavan yksimielisyyden" (overlapping consensus) muodossa. Tuolloinkin pyrkimyksenä on luoda puitteet vastakkaisten, eettisten hyvää koskevien käsitysten rakentavalle rinnakkaiselolle, jossa osapuolet tunnustavat keskinäisen erimielisyytensä luonteen ja pysyvyyden (vrt. E; ; ks. myös ECC, 193-6). Sekä agonistisen että poliittisen liberalismin yhteys ajatukseen olennaisesta kiistanalaisuudesta on nähdäkseni pintapuolista syvempi.

\section{JOHTOPÄÄTÖKSET}

Olennainen kiistanalaisuus on ilmiö, jota voidaan tarkastella hedelmällisesti useasta näkökulmasta. Olen jäsentänyt neljä pääasiallista tulkintakehystä, joiden puitteissa ilmiöstä ja sen alkusyistä esitetään eriäviä tulkintoja. Nähdäkseni olennainen kiistanalaisuus ei ole mielekkäimmin ymmärrettävissä käsitekeskeisestä näkökulmasta käsin. Väitettä siitä, että sosiaalisen oikeudenmukaisuuden ja demokratian kaltaiset käsitteet eroavat muista käsitteistä sisäsyntyisten ominaisuuksiensa tai piirteidensä puolesta, on vaikeaa osoittaa paikkansapitäväksi. Gallien käsitys, jonka mukaan kiistojen aitous ja yhtenäisyys taataan vetoamalla osapuolten jakamaan eksemplaariin, on myös hyvin ongelmallinen kyseisestä näkökulmasta. Käsitekeskeisen tulkintatavan sijaan olen pyrkinyt analysoimaan kiistanalaisuuden ilmiötä sosiaalisessa, historiallisessa ja poliittisessa kehyksessä sekä jäsentämään kyseisten tulkintalinjojen perusteita ja ominaispiirteitä ${ }^{43}$.

Sosiaalisessa tulkintalinjassa erimielisten osapuolten asema itse kiistassa korostuu. Huomiota kiinnitetään yksittäisten käsitteiden olemuksen ja piirteiden sijaan käsitteiden käyttötapoihin ja niiden käyttäjiin. Käsitteiden asema olennaisesti kiisteltyinä on sosiaalisen tulkinnan mukaan seurausta yhteiskunnallisista prosesseista, käytännöistä $\mathrm{ja} /$ tai ihmisten välisten suhteiden (rakentumisen) logiikasta. Epistemologiset, psykologiset ja loogiset kiistanalaisuuden aikaansaavat rajoitteet onkin syytä nähdä inhimillistä ajattelua ja ymmärrystä olennaisesti ohjaavina, ei niinkään esteinä, joiden poissa ollessa viime kädessä oikea vastaus voitaisiin periaatteessa saavuttaa. Kilpailevat ja toisilleen vastakkaiset käsitykset ilmenevät sosiaalisten käytäntöjen puitteissa määrittäen samalla kyseisiä käytäntöjä. Instituution, käytännön tai tradition diakroninen jatkuvuus ohjaa henkilöiden tai ryhmien käsitysten sisältöä asettaen samalla puitteet kiistelylle näistä käsityksistä. Sosiaalisessa tulkintakehyksessä onnistutaan myös selittämään käsitekeskeistä tulkintakehystä paremmin, miksi osapuolet ovat motivoituneita käymään kiistoja, joilla ei ole lopullista ratkaisua. Kiistellyt käsitteet ja sosiaaliset käytännöt vaikuttavat perustavasti toisiinsa. Oli kyse sit- 
ten hyökkäyksestä tai puolustuksesta,"erävoittojen" saavuttaminen näissä kiistoissa merkitsee sosiaalisen todellisuuden säilyttämistä tai asteittaista muuttamista itselleen mieluisaan suuntaan. Kielelliset normit, yhteiskunnalliset arvot ja normit sekä muut sosiaaliset tekijät ovat yhteen kietoutuneita. Osallistuminen jaettuihin ja jatkuviin käytäntöihin mahdollistaa kiistojen mielekkyyden ja aitouden.

Historiallisessa tulkintakehyksessä käsitteiden todellinen luonne, ja siten niiden olennainen kiistanalaisuus, ei ole ymmärrettävissä irrallaan kulttuurillisesta ja historiallisesta viitekehyksestä, jota ilman ymmärryksemme jää väistämättä puutteelliseksi. Käsitteiden olennainen (tai immanentti) historiallisuus voidaan ymmärtää toisaalta rationaalisesti perustellun viime kädessä oikean märitelmän pysyvänä puuttumisena, ja siten rajoitteena, tai uudet merkitykset ja käsiteryhmittelyt alati mahdollistavana tekijänä. Olennaisen kiistanalaisuuden historiallisen tulkinnan ei tarvitse sortua geneettiseen virhepäätelmään; eikä liioin kyseessä ole välttämättä historistinen näkemys. Vahvimman historiallisen teesin mukaan olennainen kiistanalaisuus on intellektuaalisen historian aikaansaama tosiasia, jota ei voi paeta. Mikäli modernien poliittisten diskurssien ytimen "maailmankatsomuksellista tyhjyyttä" ei voi sovittaa osoittamatta samalla korvaavan diskurssin ytimen perusteettomuutta, kiistanalaisuuden olennaisuus on tällöin seurausta mahdottomuudesta kiinnittää merkityksiä sitovasti modernien poliittisten kielten puitteissa. Ajatus olennaisesta kiistanalaisuudesta historiallisena ja loogisena välttämättömyytenä johtaa luontevasti "postmodernistisiin" painotuksiin ${ }^{44}$. Vahvan historiallisen käsityksen ansiot ilmenevät kiistanalaisuuden olennaisuuden ja alkusyyn selvässä jäsentämisessä. Näin ei nähdäkseni kuitenkaan tavoiteta kovin hyvin esimerkiksi sitä, miksi olemme motivoituneita käymään loputtomia kiistoja tietoisina kyseisten kiistojen todellisesta luonteesta. Sosiaalisen tulkintakehyksen mukainen teesi suoriutuu siinä huomattavasti paremmin. Kokonaisia aika- kausia käsittävien väitteiden todentaminen on epäilemättä myös mutkikasta.

Jotta poliittinen ymmärtämämme kaltaisena olisi ylipäätään mahdollista, tulee käsitteiden tai käsitteitä heijastavien käsitysten olla ainakin jossain määrin kiistanalaisia. Mitä politiikka ja poliittinen on, on jo itsessään poliittinen kysymys. Mutta onko olennainen kiistanalaisuus seurausta poliittisesta logiikasta (poliittisesta ontologiasta, poliittisen konstituoitumisesta) samassa mielessä kuin sosiaalisessa tai historiallisessa tulkintalinjassa? Väitän, että vastauksen täytyy olla "ei". Olennaisen kiistanalaisuuden ilmiö itsessään voidaan kenties perustellusti nähdä poliittisena ulottuvuutena diskursseineen ja käytäntöineen (tai jopa konstituoivan itse poliittista). Sosiaalisen ja historiallisen tulkintalinjan erittelyn jälkeen olennaisen kiistanalaisuuden alkusyy on kuitenkin luontevimmin nähtävissä jommankumman (tai molemman) tulkintakehyksen puitteissa. Poliittiset käytännöt ovat epäilemättä sosiaalisia käytäntöjä, ja poliittisiksi kutsumamme arvostelmat, teot ja ilmiöt ovat kulttuurillisesti ja historiallisesti kontingentteja. Kutsumme sellaisia arvostelmia, tekoja ja ilmiöitä "poliittisiksi", joista kiistellään tietynlaisen sosiaalisen (ja historiallisen) käytännön puitteissa ${ }^{45}$. Mikäli olennainen kiistanalaisuus voidaan johtaa "poliittisen" erityisiä ilmentymismuotoja perustavasta sosiaalisesta logiikasta, ei se vähennä tippaakaan poliittisten ilmiöiden merkitystä tai niiden tutkimisen tärkeyttä. On myös mahdollista, että ajatusta syvästä kiistanalaisuudesta ei voida uskottavasti laajentaa toiminnallista kiistanalaisuutta "pidemmälle", mikäli olennaisen kiistanalaisuuden ilmiö osoittautuu lähemmässä tarkastelussa lopulta liian hajanaiseksi.

Yrityksessä hahmottaa olennaisen kiistanalaisuuden ilmiötä voi olla kyse yhteensopimattomien ja jopa toisensa kumoavien sosiaalista todellisuutta koskevien intuitioiden, asenteiden ja arvostelmien jäsentämisestä mielekkääksi kokonaisuudeksi. Tarkoituksenani on ollut kuvata ilmiötä monipuolisesti, 
vaikka joudunkin tunnustamaan vasta raapaisseeni pintaa. Lisäksi tulisi analysoida $a i-$ nakin itse kiistan luonnetta ja rakennetta sekä kiistelevien osapuolien tulkintojen ja toiminnan merkitystä kiistan erityisluonteen määrittymisessä. Ilman kokonaisvaltaista ja tarkkaa analyysia on vaikea nähdä, kuinka olennaista kiistanalaisuutta koskevat, puoltavat ja vastustavat, intuitiot suhteutuvat toisiinsa nähden. Esittämäni neljän tulkintalinjan kehys on eräs mahdollinen työkalu, jolla voidaan jäsentää erityisesti kiistanalaisuuden alkusyytä ja olennaisuutta koskevia käsityksiä. Näkemykseni mukaan olennaisen kiistanalaisuuden ilmiö on hedelmällisimmin tavoitettavissa sosiaalisen tulkintakehyksen puitteissa, vaikkakin analyysia tulee täydentää, ja koetella, muiden näkökulmien esiintuomilla vahvuuksilla. Ilmiön rikkauden säilyttämiseksi tarvitaan sekä meta-analyysiä että "arkipäivän empiriaa”. Jotta voitaisiin selvittää, mikä on olennaisen kiistanalaisuuden ja nykyisten yhteiskunnallisten olosuhteiden sekä poliittisen ja/tai historiallisen itseymmärryksemme välinen suhde, tulisi näitä yhteyksiä analysoida tarkemmin tulevaisuudessa.

Miksi tulisi enää palata kysymykseen olennaisesti kiisteltyjen käsitteiden

\section{VIITTEET}

1. Kiitän Jyväskylän yliopiston filosofian yksikön jatkoopintoseminaariin keväällä 2014 osallistuneita opiskelijoita sekä seminaarin organisoijia, Sara Heinämaata ja Jussi Backmania, huomioista artikkelin aiempaa versiota koskien. Erityiskiitokset haluan osoittaa professori Heinämaalle lukuisista kielellisistä sekä sisällöllisistä korjauksista ja parannusehdotuksista. Arvioitsijoiden kommentit ovat myös johtaneet paikoin selviinkin muutoksiin. Tekstiin mahdollisesti edelleen jääneet epätarkkuudet ja virheellisyydet ovat omiani.

2. Termin "essentially contested concept" kääntäminen suomen kielelle on ongelmallista. Kun Gallien alkuperäisen teorian erityispiirteet pyritään tavoittamaan mahdollisimman tarkasti, termi "kyseenalaistettu" voisi tavoittaa "kiisteltyä" paremmin Gallien kuuden- mahdollisuudesta? Nähdäkseni useimmat olennaista kiistanalaisuutta koskevat teesit voidaan sijoittaa erilaisten vakiintuneiden teoreettisten näkökohtien ja koulukuntarajojen välimaastoon. Esitetyt näkemykset ovat huomionarvoisia erityisesti siksi, että ne haastavat ja koettelevat sementoituneiden ajattelutapojen rajoja sen sijaan, että antaisivat lopullisia vastauksia tarkkarajaisiin kysymyksiin. Olennaisen kiistanalaisuuden puolestapuhujat ovat saaneet osakseen paljon kritiikkiä - suuren osan siitä ollessa täysin ansaittua. Samoin on Gallien teorian laita. Kuitenkin tärkein syy siihen, miksi niin monet yhä edelleen inspiroituvat hänen näkemyksistään - allekirjoittanut mukaan lukien - on se, että teoria pitää sisällään jonkin oivalluksen, joka tuntuu tavoittavan hedelmällisellä ja ajatuksia herättävällä tavalla sosiaalista elämäämme olennaisesti koskevan asiantilan. Väitän tuon oivalluksen liittyvän kiistelyn tapaan, ei niinkään kiistoissa usein käytettyjen käsitteiden erikoislaatuisuuteen muihin käsitteisiin nähden. Gallien alkuperäisen teorian epäselvyyksistä huolimatta hänen julki tuomansa haaste teoreettisen ymmärryksemme puitteiden ja rajojen arvioimiseksi on epäilemättä tarttumisen arvoinen nyt ja tulevaisuudessa.

nen ehdon, eksemplaariin, näille käsitteille asettamat puitteet. Kielen sujuvuuden ja Gallien teoriasta käydyn jatkokeskustelun helpottamiseksi on perusteltua päätyä kuitenkin "kiisteltyyn". "Kiistelty" puolestaan tulee erottaa muodosta "kiistanalainen" (vrt. kpl. 3; modaliteetti). Kun Gallien teorian tulkinnallisuus otetaan huomioon, hänen erityisen näkemyksensä esittelyssä on syytä käyttää termiä"kiistelty"'kiistanalaisen" sijaan. Tässä artikkelissa englanninkieliset termit "contested" ja” contestable" on siis kautta linjan käännetty termeillä "kiistelty" ja "kiistanalainen". Toisaalta on myös hyvä pitää mielessä, että termi "contestability" viittaa englannin kielessä lakioikeuteen, ja se on käännettävissä "moitteenvaraiseksi pätemättömyydeksi". Myös tästä olennaisessa kiistanalaisuudessa on eittämättä kyse.

3. W.B. Gallie esittää alkuperäisen teoriansa artikkeleissa "Essentially Contested Concepts" (1956a: tästedes 
lyhennetty ECC) ja "Art as an Essentially Contested Concept"(1956b: ART) sekä kirjassa Philosophy and the Historical Understanding (1964: PHU), jonka yhdeksi luvuksi ECC-artikkeli on muutamin muutoksin liitetty. ECC on näistä selvästi viitatuin, ja se on uudelleenjulkaistu Max Blackin toimittamassa kokoelmassa The Importance of Language (Gallie 1962). Gallien tekstejä ei ole tietääkseni suomennettu.

4. W.B. Gallie pyrki tosin tekemään pesäeroa wittgensteinilaiseen perinteeseen hylätessään aiemmin kannattamansa käsityksen käsitteiden perheyhtäläisyydestä. Yhtenä Gallien eksplisiittisenä tavoitteena oli ylittää käsitteitä ja kieltä korostavan filosofiaperinteen (itse itselleen asettamat) rajoitteet. Yhteyksistä myöhäiswittgensteinilaiseen perinteeseen, ks. Collier et al. 2006; Vincent 2004, 95-104; vrt. Gallie 1948; ART, erit. 101. Analyyttisen ja historiallisen lähestymistavan yhteydestä, ks. ECC, 196-8; ks. myös käsillä olevan artikkelin kappale Historiallinen ymmrrys. Gallien teoriasta osana analyyttisen filosofian kritiikkiä, huom. myös Ricciardi 2000.

5. Ks. esim. Vincent 2004, 111; Criley 2007, 19; Guest 2013, 73-4. Vrt. kuitenkin Bevir\&Galisanka 2012, 713-6 wittgensteinilaisesta vaikutuksesta Rawlsin filosofiaan.

6. Palaan tähän asiaan myöhemmin. Gallien teorian läpitunkeutuneisuudesta erityisesti angloamerikkalaisiin poliittisiin tieteisiin, ks. esim. Vincent 2004, 108.

7. Esitän yleisluontoisen katsauksen olennaisesta kiistanalaisuudesta W.B. Gallien artikkelista suoraan seuranneen keskustelun pohjalta. En siis esimerkiksi esitä epistemologista analyysia käytyjen kiistojen lopullisen ratkeamattomuuden mahdollisuudesta (ks. mm. Fogelin 1985; Kölbel 2004). Lienee syytä myös korostaa, ettei tekemääni jaottelua neljään ensisijaiseen tulkintalinjaan ole tietääkseni esitetty tällaisenaan aiemmin.

8. John Gray toteaa, että hänellä ei ole mitään vastaansanomista viiden ensimmäisen ehdon osalta, mutta kaksi jälkimmäistä ehtoa paljastavat "järjestelmällisen monimerkityksisyyden alan" Gallien esityksessä (Gray 1978, 390-1).

9. K.I. MacDonald on todennut, että olennainen kiistely käsitteestä vaatii sen, että kiistelyn asianmukaiseksi perustaksi nähdään käsitteen perusolemus. Erimielisyydet ovat tällöin käsitteen olennainen osa (ks. MacDonald 1976, 381). Vrt. Gellner (1974, 95-6 lainattu myöhemmin).

10. Ks. erit. Gray 1977; 1978. Monet Gallien ehdoista, kuten vaikkapa avoimuus $\left(\mathrm{E}_{4}\right)$, kuvaavat yhtä lailla luonnontieteellisten kuin ihmistieteellistenkin käsitteiden ominaispiirteitä. Ongelmana on siis kyetä esittämään jokin (joitakin) käsitteellinen ominaispiirre, joka on joidenkin yhteiskunnallisten käsitteiden (esim. demokratia) ominaisuus, mutta ei toisten (esim. identiteetti). Tai vaihtoehtoisesti: miksi ihmistieteiden käsitteet olisivat olennaisesti kiistanalaisia, jos samaa ei voida tai haluta sanoa luonnontieteissä käytetyistä käsitteistä? Käsitteiden arvottavuutta sinänsä on pidetty yhtenä varteenotettavana erottavana tekijänä, mutta esim. Pekka Väyrysen mukaan Gallien esiin nostamat piirteet ovat useille sekä evaluatiivisille että ei-evaluatiivisille käsitteille tyypillisiä (ks. Väyrynen 2014).

11. Kyseessä voi olla viime kädessä epäaito kaksijako. Asiaa ei kuitenkaan ole mahdollista tämän kirjoituksen puitteissa tarkasti analysoida huomioni ollessa erilaisissa Gallien teesin tulkintalinjoissa, joiden menestystä ja asianmukaisuutta arvioidaan verrattain rajallisessa kehyksessä.

12. Ks. Gray 1977, 338; Ball 2002, 24-5 ja vrt. Ball 2000, 35; Zimmerling 2005, 23.

13. Teesi ei ole tällaisenaan täysin ongelmaton, sillä ilman lisämääreitä joudutaan hyväksymään olennaisesti kiistanalaisiksi myös joukko käsitteitä,joista ei ole koskaan aktuaalisesti kiistelty. Looginen mahdollisuus, ettei kyseisistä käsitteistä tulla myöskään koskaan kiistelemään, tekee tästä väitteestä kenties intuitiivisesti epäuskottavan.

14. Osiossa Historiallinen ymmärrys käsittelen vielä tarkemmin Gallien eksemplaarivaatimusta kohtaan esitettyä kritiikkiä. Yhdessä tämän osion huomioiden kanssa siitä käy nähdäkseni selväksi, ettei Gallien teesiä olennaisesta kiistanalaisuudesta voi tulkita käsitekeskeisestä näkökulmasta ilman huomattavia muutoksia.

15. Ks. Freeden 1996, 56-60 ja Besson 2005, 80-1. Intensiosta ja ekstensiosta (sekä konnotaatiosta ja denotaatiosta) erityisesti yhteiskuntatieteellisten käsitteiden analysoinnin yhteydessä, ks. Sartori 1984.

16. On epäselvää, olisiko tällöin kyseessä sama abstrakti ideaali, josta Gellner puhuu kritisoidessaan Gallien käsitystä eksemplaarista, ks. §5. Lisäksi: vaikka pyrinkin tässä tekemään Gallien perusajatusta ymmärrettäväksi käsitekeskeisestä näkökulmasta, on kokonaan 
eri asia väittää, että Gallien teesi kaikkine puutteineen pitäisi sisällään rakennusaineet uskottavaan käsitekeskeiseen teesiin olennaisesta kiistanalaisuudesta.

17. William Connollyn uudelleentulkinta on epäilemättä ollut yksi vaikutusvaltaisimmista. Hänen teoriansa voidaan käytännössä ulottaa koskemaan kaikkia poliittisia ja yhteiskunnallisia käsitteitä (Ricciardi 2000, 42-3), mikä lienee laajentanut sitä, mitä pidetään nykyään myös Gallien tarkoittamana teesinsä kattoalana. Käsitteiden olennaisen kiistanalaisuuden Connolly määrittää Gallieta mukaillen kolmen ehdon - arvottavuuden, monimutkaisuuden ja avoimuuden kautta. Tällaiset käsitteet ovat sisäisesti monimutkaisia "rypäskäsitteitä", joiden määrittelyn tekee hankalaksi niiden koostuminen useista toistensa kanssa kenties loogisestikin yhteen sovittamattomista kriteereistä. Näiden kriteereiden mahdolliset muotoilut koostuvat käsitteellisistä ilmaisuista, joista voidaan yhtä lailla kiistellä. Ks. lisää Connolly 1993.

18. Gallien teoriasta haetaan tyypillisesti tukea (ja prestiisiä) koettaessa tarpeelliseksi korostaa, että jostain asiasta on esitetty lukuisia toisilleen vastakkaisia näkemyksiä - mikä ei vielä siis tarkoita niiden olennaista kiistanalaisuutta.Jeremy Waldron onkin todennut, että"termin käyttötavat rehottavat villeinä” (Waldron 2002, 148).

19. Huomaa kuitenkin Gallien toteamus siitä, missä mielessä ilmiötä ei tarvitse selittää metafyysisiin erimielisyyksin tai psykologisiin taipumuksiin vedoten (ECC, 169).

20. En oleta, että tähänastinen esitykseni riittäisi vakuuttamaan lukijan tästä asiasta.Jää asiakseni näyttää, mikä tulkintakehys, ja mistä syistä, tavoittaa Gallien tarkoituksen paremmin.

21. Barry Clarken mukaan olennaisesti kiistellyistä käsitteistä ei voi mielekkäästi puhua yhteiskunnallisesta näkökulmasta, koska se tekisi käsitteellisistä kiistoista ei-olennaisia kiistojen luonteen ja lopputuloksen seuratessa suoraan yhteiskunnallisesta rakenteesta (Clarke 1979). Clarken argumentti perustuu nähdäkseni ajattelulle, jossa kieli ja yhteiskunta (tai konteksti, jossa kieltä käytetään) erotetaan toisistaan hyvin jyrkällä ja epäuskottavalla tavalla. Toisaalta kyse on siitä, mitä "olennaisuuden"katsotaan tässä yhteydessä implikoivan.

22. Gray on esittänyt olennaisesti kiisteltyjä käsitteitä koskevat huomionsa kolmessa toisistaan merkittävästi poikkeavassa artikkelissa (1977, 1978 ja 1983/1993).
Hän on kritisoinut olennaisen kiistanalaisuuden puolesta puhuneiden Steven Lukesin (1974) ja William Connollyn (1993/1974) näkemyksiä "vallasta" ja on päätynyt vastustamaan "olennaisen kiistanalaisuuden inflatorisen idiomin" käyttöä sosiaalisen ajattelun rajallisuuden tarkastelussa (Gray 1993,237). Grayn ilmiötä koskevat huomiot ovat tarkkoja ja hyödyllisiä, ja niihin myös viitataan usein kirjallisuudessa. Hän ei tosin missään kohtaa käsittele Gallien alkuperäistä teoriaa suoraan Gallien omia muotoiluja hyödyntäen.

23. Gallien arvostelijat ovatkin kiinnittäneet paljon huomiota hänen termivalintaansa, jonka johdosta hänen teoriansa on nähty johtavan jopa kaikenlaisten rationaalisten standardien puuttumiseen ja sosiaalisen kommunikaation mahdottomuuteen (vrt. esim. Ball 2000, 34-5; 2002, 23-4). Olennaisuus tai "essentiaalisuus" voidaan ymmärtää kuitenkin monin eri tavoin. On syytä olettaa, että Gallie tarkoitti sillä lähinnä sitä, että erimielisyys on erottamaton (eli tässä mielessä”olennainen”) osa käsitteen käyttökelpoisuutta, mutta muitakin aivan päteviä tulkintavaihtoehtoja on (Waldron 1994, 529-30.)

24. John Gray on huomauttanut, että käsitteiden olennaista kiistelyä ei esiinny kaikissa yhteiskunnissa (Gray 1977, 336). Toisaalta yhteiskunnalliset olosuhteet kuitenkin vaikuttavat hänen mukaansa kiistelyyn käsitteistä muutenkin kuin vain yksikantaan sen mahdollistaen.

25. Tässäeiole mahdollista arvioida, mitäilmaus"sosiaalisten suhteiden rakentumisen logiikka” tosiasiallisesti pitää sisällään ja vaatiiko teesi olennaisesta kiistanalaisuudesta hyväksymään jonkin tietyn käsityksen, kuten poliittisen identiteetin muodostuminen me/muut-eronteon kautta tai hegeliläisen herra/orja-dialektiikan käsitys sosiaalisista suhteista ja identiteetistä

26. Tähän liittyen, ks. ART, 108.

27. Artikkelissaan "The Essential Contestability of Some Social Concepts" (1973) MacIntyre ei suoraan kommentoi tai analysoi W.B. Gallien alkuperäistä teoriaa, vaikka hän toteaakin "lainaavansa" häneltä ilmauksen "essentially contestable" (MacIntyre 1973, 7). Sekä John Gray että MacIntyre ovat samaa mieltä siitä, että käsitteen avoin luonne tai rakenne (open texture) ei itsessään kykene tekemään käsitteestä olennaisesti kiisteltyä (Gray 1977,392-3; MacIntyre 1973). Grayn ja MacIntyren näkemyksien eroavuudesta käsitteiden perustavan epätäydellisyyden suhteen, ks. Gray 1977. 
28. Käsitteiden refleksiivisyydestä, ks. myös Gray 1978, 393 ja Besson 2005, 81.

29. Jotta kiistely voi päästä alkuun, tulee osapuolten välillä olla toki jonkinlainen minimaalinen jaettu ymmärrys koskien asianmukaisia käsitteellisiä ja sisällöllisiä seikkoja. Tämä ei kuitenkaan poissulje olennaisen kiistanalaisuuden mahdollisuutta, ks. Besson 2005, 80-9. Susan Hurley:n mukaan kiistan aitouden problematisointi (käsitekeskeisestä näkökulmasta) perustuu vääriin "ultratulkintoja" vaativiin oletuksiin siitä, mitä "käsitteellistä" osapuolten tulee jakaa.Hänen mukaansa "erimielisyyden käsitteellinen locus on osallistuminen maailmaan upotettuihin käytäntöihin ja tapoihin, ja käsitteellisen eroavuuden kriteeri on kykenemättömyys osallistua kyseisiin käytäntöihin” (Hurley 1989, 49).

30. Ricciardin mukaan Gallie on joissakin väitteissään väärässä ja hänen virheensä ovat historismille tyypillisiä (Ricciardi 2000, 41-2). Gallie oli tietoinen tämänkaltaisten vastaväitteiden mahdollisuudesta eikä katsonut itse sortuvansa vääränlaiseen historismiin (ECC, 198; ks. myös ECC, 196-7). Yhteiskuntatieteellisten käsitteiden analysoinnissa on rekonstruktiolla, jossa selvitetään tarvittaessa myös käsitteen historiallisia käyttöjä, joka tapauksessa merkittävä rooli (ks. Sartori 1984).

31. Edward Damer määrittää geneettisen virhepäätelmän seuraavasti: "Asiaa arvioidaan ensin sen aiemman kontekstin puitteissa, minkä jälkeen kyseinen arviointi katsotaan nykyistä asiantilaa koskevaksi huomioimatta olennaisia muutoksia, jotka ovat mahdollisesti vaikuttaneet asian luonteeseen tuolla välin" (Damer 2009, 93).

32. Käsitteen tulee olla johdettavissa "alkuperäisestä eksemplaarista, jonka auktoriteetin kaikki kilvoittelevat käsitteen käyttäjät tunnustavat”(ECC, 180; PHU, 168).

33. Ernest Gellnerin mukaan tämä tekee käsitteestä ongelmallisesti "menneisyyden panttivangin" (Gellner 1974, 96; vrt. Freeden 2004, 8). John Gray tosin toteaa, että Gallie ei suoraan syyllisty loogiseen virhepäätelmään (Gray 1978, 390). Kuitenkin:"Gallie on väärässä olettaessaan, että hyväksytty eksemplaari on aina tai edes tyypillisesti läsnä tämänkaltaisissa kiistoissa” (mts.)

34. Alasdair MacIntyren mukaan yhteiskunnallisia yksilöolioita (social particulars) koskeva lainalaisuuden puute ilmenee muun muassa niitä koskevissa kiistoissa. Emme voi edes jälkikäteen löytää aiemmista konflikteistamme ja argumenteistamme tekijöitä,jotka olisivat mahdollistaneet toteutuneen lopputuloksen ennustamisen. (MacIntyre 1973, 5-6.)

35. Tämän erottelun on tehnyt Elías Palti (2005), jonka huomioihin nojaudun vahvasti osion loppuun asti.

36. Esimerkiksi Hans Blumenbergin sekularisaatioteorian mukaan modernin ajan ihmiset eivät ole kyenneet sekularisoimaan vanhojen uskonnollisten oppien perintöään, mistä on seurannut käsitteellinen tyhjiö. Jokainen sekulaari järjestys voidaan tällöin nähdä perustoiltaan radikaalisti satunnaisena - vailla mieltä olevana, irrationaalisena - tai toisin sanoen: modernien eettisten ja poliittisten diskurssien ydinkategoriat ovat olennaisesti kiistanalaisia. (Palti 2005,116-7.) Alasdair MacIntyre esittää kirjassaan Hyveiden jäljillä (2004) samankaltaisen teesin. Ks. myös MacIntyre 1967, 266-8.

37. Huolimatta tässä tekstissä tehdyistä tulkintakehysten ja -linjojen toisistaan erottamisesta, on kuitenkin niin, ettei kaikkia erityisiä käsityksiä olennaisesta kiistanalaisuudesta ole mahdollista, tai edes toivottavaa, pakottaa vain yhteen tulkintalinjaan kuuluvaksi. Esimerkiksi Michael Freedenin (1996) näkemyksen ideologisen morfologian ja olennaisesta kiistanalaisuuden yhteydestä sekä William Connollyn (1993) käsityksen olennaisesti kiistellyistä käsitteistä voi vaihtelevin perustein sijoittaa ainakin käsitekeskeiseen ja poliittiseen tulkintalinjaan kuuluviksi.

38. Tässä asiassa käsillä oleva tekstikään ei tee valitettavasti poikkeusta.

39. Vaikkapa siten, että jossain kulttuurissa jonain historiallisena hetkenä olisi saatavilla vain yksi oikea vastaus, jonka kukin asiaa rationaalisesti pohtimalla sekä aikaa ja vaivaa nähden voisi saavuttaa.

40. Kyseisten käsitteiden "epäkyseenalaistaminen" (decontestation) tarkoittaa nimenomaan (olennaisesti) kiistanalaisten käsitteiden merkityksen kiinnittämistä, mutta asiaa ei voida tässä yhteydessä avata enempää. Ks. Freeden 1996.

41. Tämän on huomioinut mm. John Gray jo yli 30 vuotta sitten (ks. erit. 1977,335-7). Gallien teoriasta käydyssä keskustelussa asialle ei ole kuitenkaan nähdäkseni annettu riittävää painoarvoa.

42. Ennen kaikkea olisi syytä arvioida, mikä tarkalleen ottaen on olennaisen kiistanalaisuuden suhde ajatukseen järkeenkäyvästä erimielisyydestä (reasonable disagreement)? 
43. On syytä painottaa, että tässä osiossa esitetyt johtopäätökset ovat yleisluonteisia ja tarkoitettu lähinnä helpottamaan tulevan tutkimuksen kohdentamista. Täten en väitä osoittaneeni, että teesi olennaisesta kiistanalaisuudesta on viime kädessä paikkansapitävä yhdenkään esitetyn tulkintakehyksen puitteissa.

44. Käytän tässä termiä "postmoderni” Tuija Pulkkisen (1998) luonnehdinnan mukaisesti. Moderni

\section{KIRJALLISUUS}

Ball, Terence (1988) Transforming Political Discourse. Oxford ja New York: Basil Blackwell.

Ball, Terence (2000) "From Hobbes to Oppenheim: Conceptual reconstruction as political engagement", teoksessa Ian Carter ja Mario Ricciardi (toim.) Freedom Power and Political Morality: Essays for Felix Oppenheim, Houndmills, Basingstoke: Palgrave Macmillan, 20-38.

Ball, Terence (2002) "Confessions of a Conceptual Historian”, Finnish Yearbook of Political Thought 6: 11-31.

Ball,Terence (2006)"Must Political Theory Be Historical?" Contributions to the History of Concepts 2(1): 7-18.

Bevir, Mark \& Gališanka, Andrius (2012) "John Rawls in Historical Context", History of Political Thought 33(4): 701-725.

Besson, Samantha (2005) Morality of Conflict: Reasonable Disagreement and the Law. Oxford and Portland, Oregon: Hart Publishing.

Boromisza-Habashi, David (2010) "How Are Political Concepts 'Essentially' Contested?", Language E Communication 30: 276-284.

Care, Norman (1973)"On Fixing Social Concepts", Ethics 84(1): 10-21.

Clarke, Barry (1979) "Eccentrically Contested Concepts", British Journal of Political Science 9(1): 122-126.

Collier et al. (2006) "Essentially Contested Concepts: Debates and applications" (Collier D; Hidalgo F.D; ja Maciuceanu A.O), Journal of Political Ideologies 11(3): 211-246.

Connolly, William E. (1993) The Terms of Political Discourse [1. painos 1974]. Princeton: Princeton University Press.

Criley, Mark (2007) "Contested Concepts and Competing Conceptions", väitöskirja, University of Pittsburgh.

Damer, Edward (2009) Attacking Faulty Reasoning: A Practical Guide to Fallacy-Free Arguments. Belmont, Kalifor- ajattelutapa pyrkii paljastamaan ilmiöiden perustan. Postmodernissa lähestymistavassa ilmiöille ei ajatella perustavaa ydintä ja perustahakuisuus hylätään. (Pulkkinen 1998, 9-10.)

45. Tästä osaltaan kielivät myös tekemäni havainnot olennaisen kiistanalaisuuden ja liberalistisen yhteiskunnan (itseymmärryksen) välisistä yhteneväisyyksistä.

nia: Wadsworth Cengage Learning.

Dworkin, Ronald (1978) Taking Rights Seriously. Lontoo: Duckworth.

Freeden, Michael (1996) Ideologies and Political Theory: A conceptual approach. Oxford: Clarendon Press.

Freeden, Michael (2004) "Editorial: Essential contestability and effective contestability", Journal of Political Ideologies 9(1): 3-11.

Fogelin, Robert (1985) "The Logic of Deep Disagreements", Informal Logic 7(1): 1-8.

Gallie, Walter Bryce (1948) "The Function of Philosophical Aesthetics", Mind, New Series, 57: 227, 302-321.

Gallie, Walter Bryce (1949) "The Limitations of Analytical Philosophy", Analysis 9(3): 35-43.

Gallie,Walter Bryce (1956a/ECC) "Essentially Contested Concepts", Proceedings of the Aristotelian Society, New Series, 56 (1955-1956), 167-198.

Gallie, Walter Bryce (1956b/ART) "Art as an Essentially Contested Concept", The Philosophical Quarterly 6(23): 97-114.

Gallie, Walter Bryce (1962) "Essentially Contested Concepts", teoksessa Max Black (toim.) The Importance of Language, Englewood Cliffs, N.J: Prentice-hall, Inc, 121-46.

Gallie,Walter Bryce (1964/PHU) Philosophy and Historical Understanding. Lontoo: Chatto \& Windus.

Gellner, Ernest (1974) "The Concept of a Story", teoksessa Contemporary Thought and Politics. Lontoo ja Boston: Routledge \& Kegan Paul, 95-112.

Gray, John (1977) "On the Contestability of Social and Political Concepts", Political Theory 5(3): 331-348.

Gray, John (1978) "On Liberty, Liberalism and Essential Contestability", British Journal of Political Science 8(4): 385-402.

Gray, John (1993) "Political Power, Social Theory and Essential Contestability", teoksessa Post-liberalism: Studies in political thought. New York: Routledge, 216-237. 
[Julkaistu alun perin 1983 teoksessa D. Miller ja L. Siedentop (toim.) The Nature of Political Theory, Oxford: Clarendon Press.]

Guest, Stephen (2013) Ronald Dworkin. Stanford, Kalifornia: Stanford University Press.

Habermas, Jürgen (2006) Dialectics of secularization: on reason and religion (yhdessä Joseph Ratzingerin kanssa). San Francisco: Ignatius Press.

Hurley, Susan (1989) Natural Reasons: Personality and polity. New York: Oxford University Press.

Kölbel, Max (2004) "Faultless Disagreement", Proceedings of the Aristotelian Society, New Series, 104: 53-73.

Lukes, Steven (1974) Power: A radical view. Lontoo: Macmillan.

MacDonald, K.I. (1976) "Is 'Power' Essentially Contested?” British Journal of Political Science 6(3): 380-382.

MacIntyre, Alasdair (1967) A Short History of Ethics. Lontoo: Routledge and Kegan Paul.

MacIntyre, Alasdair (1973) "The Essential Contestability of Some Social Concepts", Ethics 84(1): 1-9.

MacIntyre, Alasdair (2004) Hyveiden jäljillä: moraaliteoreettinen tutkimus. Suom. Niko Noponen. Tampere: Gaudeamus. [Alkuteos After Virtue: A Study in Moral Theory, 1981.]

Mason, Andrew (1993) Explaining Political Disagreement. New York: Cambridge University Press.

Mouffe, Chantal (1993) The Return of the Political. Lontoo: Verso.

Mouffe, Chantal (2000) The Democratic Paradox. Lontoo: Verso.

Mouffe, Chantal (2005) On the Political. Abingdon: Routledge.

Newey, Glen (2001) "Philosophy, Politics and Contestability", Journal of Political Ideologies 6(3): 245-261.

Palti,Elías (2005) "On the Thesis of Contestability of Concepts, and 19th Century Latin American Intellectual History". Redescriptions 9: 113-134.

Pennanen, Joonas (2012) "After Essentially Contested Concepts", pro-gradu. Jyväskylän yliopisto, yhteiskuntatieteiden ja filosofian laitos.

Pulkkinen, Tuija (1998) Postmoderni politiikan filosofia. Tampere: Gaudeamus.

Rawls,John (1993) Political Liberalism. New York: Columbia University Press.
Rhodes, Michael (2000) Coercion: A nonevaluative approach.Amsterdam: Rodopi.

Ricciardi, Mario (2000) "Essential Contestability and the Claims of Analysis", teoksessa Carter,I.ja Ricciardi, M. (toim.) Freedom, Power and Political Morality: Essays for Felix Oppenheim. Houndmills, Basingstoke: Palgrave Macmillan, 39-56.

Ruben, David-Hillel (2010) "W.B. Gallie and Essentially Contested Concepts", Philosophical Papers 39(2) 257-70.

Ruben, David-Hillel (2013) "Traditions and True Successors", Social Epistemology 27(1): 32-46.

Sartori, Giovanni (1984) "Guidelines for Concept Analysis", teoksessa Sartori, G. (toim.) Social Science Concepts: A Systematic Analysis. Beverly Hills, California: Sage Publications, Inc, 15-85.

Syrjämäki, Sami (2011) "Sins of a Historian: Perspectives on the problem of anachronism", väitöskirja. Tampereen yliopisto, yhteiskunta- ja kulttuuritieteiden yksikkö.

Swanton, Christine (1985) "On the 'Essential Contestedness' of Political Concepts", Ethics 95(4): 811-27.

Tully, James (1999) "The Agonic Freedom of Citizens", Economy and Society 28(2): 161-82.

Tully, James (2000) "Struggles over Recognition and Distribution", Constellations 7(4): 469-82.

van den Brink, Bert (2005) "Liberalism Without Agreement: Political autonomy and agonistic citizenship”, teoksessa Christman, J. ja Anderson, J. (toim.) Autonomy and the Challenges to Liberalism: Nerw Essays, 245-71.

Vincent, Andrew (2004) The Nature of Political Theory. Oxford: Oxford University Press.

Väyrynen, Pekka (2014) "Essential Contestability and Evaluation", Australasian Journal of Philosophy, DOI: 10.1080/00048402.2013.868008.

Waldron, Jeremy (1994) "Vagueness in Law and Language: Some Philosophical Issues", California Law Review 82(3): 509-40.

Waldron, Jeremy (2002) "Is the Rule of Law an Essentially Contested Concept (in Florida)?" Law and Philosophy, 21, 137-64.

Zimmerling, Ruth (2005) Influence and Power: Variations on a messy theme. Dordrecht: Springer. 